INTERNATIONAL

FOOD POLICY

RESEARCH

INSTITUTE

IFPRI

IFPRI Discussion Paper 01898

December 2019

Determinants of Migration among Rural Youth throughout the World

Alan de Brauw

Markets, Trade, and Institutions Division 


\section{INTERNATIONAL FOOD POLICY RESEARCH INSTITUTE}

The International Food Policy Research Institute (IFPRI), established in 1975, provides research-based policy solutions to sustainably reduce poverty and end hunger and malnutrition. IFPRI's strategic research aims to foster a climate-resilient and sustainable food supply; promote healthy diets and nutrition for all; build inclusive and efficient markets, trade systems, and food industries; transform agricultural and rural economies; and strengthen institutions and governance. Gender is integrated in all the Institute's work. Partnerships, communications, capacity strengthening, and data and knowledge management are essential components to translate IFPRI's research from action to impact. The Institute's regional and country programs play a critical role in responding to demand for food policy research and in delivering holistic support for country-led development. IFPRI collaborates with partners around the world.

\section{AUTHORS}

Alan de Brauw (a.debrauw@cgiar.org) is a senior research fellow in the Markets, Trade, and Institutions Division of the International Food Policy Research Institute (IFPRI), Washington D.C.

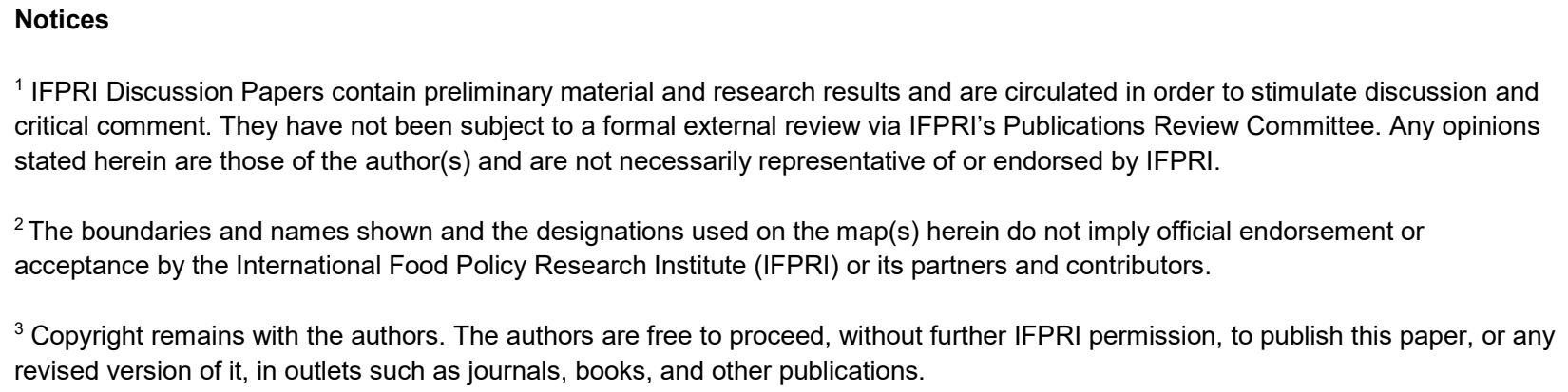




\title{
Determinants of Migration among Rural Youth throughout the World
}

\author{
Alan de Brauw ${ }^{1}$ \\ December 2019
}

\begin{abstract}
The decision of whether to migrate or not is one of several important decisions made by young men and women throughout the developing world. This paper uses panel data from five countries in Asia and Africa to examine the determinants of rural youth migration across five different countries, indirectly testing both broad and specific hypotheses related to migration. It finds that individual characteristics are more important determinants of migration than household or village characteristics. Further, it finds little evidence that credit constraints or relative deprivation are correlated with migration, holding other things constant. The difference between this result and those found in the literature regarding credit constraints implies credit constraints are geographically concentrated. The paper concludes with a discussion of the implications for migration influenced policy regarding youth, including the need for more and better migration data.
\end{abstract}

Keywords: youth, migration, relative deprivation, credit constraints

\footnotetext{
${ }^{1}$ Alan de Brauw is a Senior Research Fellow at the International Food Policy Research Institute. This work was undertaken as part of the CGIAR Research Program on Policies, Institutions, and Markets (PIM) led by the International Food Policy Research Institute (IFPRI). Thanks to Siddhartha Baral and Mike Murphy for research assistance, and Aslihan Arslan, Eva-Maria Egger, Alessandra Garbero, Dave Tschirley, and Paul Winters for comments that have improved the manuscript. Any opinions in the paper are the views of the author and not necessarily the views of the International Food Policy Research Institute.
} 


\section{Determinants of Migration among Rural Youth throughout the World}

\section{Introduction}

The transition from childhood to adulthood involves a set of decisions that affect the trajectory of each individual's life course. Between the ages of 15 and 24, young men and women make decisions, either themselves or in part with their families, about when to leave school, what type of work to do, and with whom to spend their lives. They also make decisions about where to live while making many of these decisions. In particular, they may decide to migrate away from their home village either to work or seek work.

As the number of rural youth in developing countries continues to expand (IFAD, 2019), it is important to better understand the determinants of migration decisions made by youth, and whether their determinants differ from those who are slightly older. While there is substantial evidence on the determinants of migration in general, the literature on the determinants of youth migration is relatively sparse. Exceptions include Heckert (2015) and Valentine et al. (2017), who both find that education plays an important role in both determining and constraining youth migration in Haiti and Mexico, respectively. Heckert (2015) finds that Haitians who migrate for educational opportunities, whether from rural or urban areas, end up with better labor opportunities. Valentine et al. (2017) study rural communities in southern Mexico and find that additional exposure to domestic migration is associated with more migration to periurban areas and urban areas to complete schooling, though that effect is dampened with additional exposure to international migration, which generally leads to unskilled jobs in the United States that are perceived not to require as much schooling. Yet in general there is very little quantitative information on youth migrant determinants in the literature.

This paper takes advantage of two recent developments. First, there are now several relatively large, nearly nationally representative panel data sets that can be used to study youth migration among a large sample of youth. As the panel data sets used in analysis all either track migrants or include a migration module, the migration decision is measured as a flow of individuals out of rural households between survey rounds in these data sets. In cross-sectional analysis of data sets with migration modules, migration must be measured as a "stock," so obfuscates the migrants' situation when the decision to leave is made. By measuring migration as a flow, the paper can correlate that migration flow with a standardized set of individual- and household-level observables that are almost all measured prior to migration. Moreover, cross-sectional analysis of migration is easily affected by the potential for reverse causality; by 
primarily studying the correlation between characteristics measured before migration occurs with the decision to migrate, reverse causality is no longer a concern.

The paper uses the most recent two panels from five countries: Bangladesh, Indonesia, Nigeria, Pakistan, and Tanzania. To make results comparable, the paper standardizes individual characteristics, household demographics, indicators for asset holdings, and household consumption, so results between countries are directly comparable in most cases. Further, it compares the determinants of youth migration with the determinants of migration among the next oldest cohort, 25 to 34 year olds (or young adults); differences in coefficient estimates between youth and young adults suggest specific determinants of migration that are important for youth in a relative sense.

Although most of the analysis controls for enumeration area fixed effects, they are relaxed to test hypotheses about local characteristics affecting the returns to labor and therefore potentially the propensity to migrate. Two variables are derived from the household level data, measuring the average amount of land per capita available in the village and the share of households in which a household member defines off-farm work as their primary job, both measured in the first survey. The former variable should affect the returns to labor in agriculture; if less land per capita is associated with lower returns to labor in agriculture, the incentive to migrate should increase. The presence of more local off-farm work would be correlated with higher local returns to labor, and therefore would potentially be negatively related to migration. Of course, if youth do not have equal access to either land or local off-farm labor in rural areas, then there might not be a correlation between youth migration and these variables. Finally, for four of the five countries' data coordinates were linked to external databases with variables measuring local population density and the average enhanced vegetation index over the past three years, which can both be interpreted as alternative proxies for local productivity and returns to labor.

The paper examines two further hypotheses related to migration. First, it indirectly tests whether credit constraints affect migration. If so, then the propensity to migrate should be lower among the relatively poor. Second, it directly examines the relative deprivation hypothesis, using the measure first developed by Yitzhaki (1979). Whereas this hypothesis has been previously tested (Stark and Taylor, 1991; Kafle, Benfica, and Winters, 2018), this paper tests it for a much larger set of countries than before, with better control for the flow of migrants out of rural areas. 
The paper does not differentiate between internal and international migration, but international migration can only be identified in three of the five countries, and it is relatively rare in all three. ${ }^{2}$ The measure of migration as a flow implies that fewer household members move to international destinations in each of these countries. A study of determinants of international migration among youth would likely require a specialized set of surveys (e.g. de Brauw and Carletto, 2012).

The paper shows that the determinants of migration vary substantially between countries. There is little evidence for either credit constraints affecting migration, or for relative deprivation being a determinant of migration. An immediate implication of the former finding is that more high quality data on migration would be useful in helping develop policies that can help enhance positive impacts of migration.

The paper is structured as follows. The following section describes a conceptual framework within which youth migration decisions are made. The third section discusses the data sets used in the analysis, and constraints, and the fourth section describes migration behavior within those data sets. The fifth section analyzes the data primarily in a multivariate framework, and the final section concludes.

\section{Decision Making during the School-Work Transition}

Youth, defined by the United Nations as 15 to 24 year olds, make a set of decisions that substantially affect their life course. In this section, I lay out the types of decision making that individuals typically make during this period of their life. Decisions related to employment, such as where to seek work (either locally, in labor markets that are accessible within commutable distance of home, or in distant labor markets for which one must live elsewhere) is just one of those decisions.

One of the first decisions that youth make each year, if they have not yet stopped, is whether to continue in school or not. The schooling decision trades off additional expected returns to schooling against the actual and opportunity costs of continuing in school (Kochar, 2004; Glewwe and Jacoby, 2004). When the expected returns to continuing in school no longer outweigh costs, individuals drop out and begin to search for work. Local and distant labor markets play a role in shaping both the returns to schooling and opportunity costs of schooling. Important to this paper is the role that distant labor markets might play. The opportunity cost of schooling may be shaped by perceived or actual opportunities to migrate; if, for example, migrant networks lead to better information about unskilled wages outside of rural areas among one's peers, then the perceived opportunity cost can rise, leading to individuals leaving school earlier (e.g.

\footnotetext{
${ }^{2}$ In fact, there were only three international youth migrants between the surveys used in Nigeria.
} 
de Brauw and Giles, 2017). On the other hand, information could also flow into rural areas about higher returns to schooling, potentially increasing perceived benefits to further schooling (e.g. Valentine et al., 2017).

Individuals then make decisions about whether and where to seek employment; in rural areas, the family farm is an option, but individuals can seek work in local or distant labor markets. A key challenge limiting on-farm labor is that available land per adult worker declines with population growth, so either agricultural productivity must increase or non-agricultural labor becomes more attractive relative to working in farming. Consistent with this idea, some recent evidence suggests that migration can affect local wage rates, thus strengthening this theoretical argument. Rosenzweig and Udry (2014) show seasonal migration among males responds to forecasted rainfall during the monsoon in India; a one standard deviation increase in forecasted rainfall leads to an 0.7 percentage point decrease in seasonal migration among men, translating to a two percent decline in the rural wage rate at planting. With cleaner statistical identification, Akram, Chowdhury, and Mobarak (2017) study whether exogenously influenced migration rates affect the village-level labor market long after the intervention; again studying seasonal migration among males, they find the male agricultural wage elasticity with respect to emigration is about 0.2 , yet does not change agricultural prices in the villages, as output markets are well integrated.

Beyond school and work decisions, many youth make decisions about family. First, they decide with whom and when to get married and start a household; these decisions may occur simultaneously or sequentially. These decisions are also potentially affected by school and employment decisions. In general, if individuals stay in school longer they are less likely to get married and start a household; similarly, if individuals migrate for work and plan to return home, they might delay family-related decisions.

Another type of decision that youth often make is whether to or when to start child bearing among women, or parenting children among men. These choices are affected by or affect school or employment decisions, as well as marriage or household formation. Youth remaining in school are less likely to be married or become parents than others, though one would not ascribe causality in either direction. Deciding to have children may also affect migration decisions, in either direction. As infants are time consuming, their presence could lead to more specialization within farming households, with men taking on the farming. Alternatively, if migrant opportunities are available, men might migrate after a child arrives to better provide for the child through higher earnings available away from home. 
All these decisions are affected by local factors and institutions. From the individual perspective, gender may play an important role in shaping the desire to migrate, the motivation to migrate, and potential opportunities upon migration (de Jong, 2000). From the family perspective, they are not undertaken by an individual alone, but are likely made in consultation or collaboration with family (e.g. Stark and Bloom, 1985). Social networks with extended family members or others who might have moved out of the potential migrants' home village may also play a role in facilitating migration decisions, since they can provide information about either jobs or methods to start looking (Carrington, Detragiache and Vishnawath, 1996; Munshi, 2003). Customs related to marriage, such as the presence of dowry or bride prices, and the way that land transfers from one generation to another, can affect such decisions, either positively or negatively. ${ }^{3}$ And factors such as the existence and quality of road infrastructure and information and communication technologies can shape the costs of migrating or working farther from home.

Finally, economic factors play important roles in shaping these decision-making processes. Household income, access to credit (or liquidity), and household needs for labor in either agricultural or nonagricultural self-employment may shape decisions about migration. These factors may affect both migration for earning opportunities as well as for marriage, as hypothesized by Rosenzweig and Stark (1989). In the latter case, marrying farther from one's home village can help the extended family distribute production risk, as the correlation between weather or climate shocks between two locations weakens as those locations are farther apart. More importantly, both the level and pace of structural transformation will shape opportunities for local farm or off-farm wage labor, or wage labor in places to which youth can either commute or potentially migrate. If wages in the secondary or tertiary sectors are growing faster than returns to labor in agriculture, then the pull of migration is likely to grow over time. Similarly, factors related to the environment or climate could affect returns to labor on the farm, which could affect decisions about whether to migrate (Bosetti, Cattaneo, and Peri, 2018).

\section{Decisions about mobility and migration by youth}

From the perspective of understanding mobility by youth, there are a set of decisions to make, rather than a single decision. First, one must consider whether to leave home or not, and for what purpose. Individuals move for several potential reasons, including seeking further education, looking for employment or going to jobs obtained prior to moving, or for marriage or other family reasons. A potential

\footnotetext{
${ }^{3}$ On the potential for land tenure institutions to affect migration, see for example de Janvry et al. (2015).
} 
migrant must also decide where to move, if moving. The destination is likely to be linked to the reason for moving. For example, one might have an option to attend a specific school. Alternatively, one might know of work potential in only a couple potential destinations with strong networks back to the home village. In either case, the reason for migrating and the choice of destination are linked. Different destinations have different implicit costs associated with them, and international destinations are typically more costly than internal ones. ${ }^{4}$

\section{Conceptual Framework}

Decisions about mobility and migration and interrelated with decisions made more generally about schooling, work, and employment. Therefore, the determinants of these decisions are difficult to disentangle from one another, particularly as they may relate to both observable and unobservable factors. Since there is no obvious observable factor affecting migration (or even specific migration decisions) in isolation of these other decisions, this paper seeks only to describe conditional correlations between observed migration decisions and other factors.

Although a clean identification strategy to causally understand the determinants of youth migration is not feasible, theory can help identify factors potentially correlated with migration decisions. One can think of migration as a form of labor supply from the household perspective; labor supply should then be correlated with variables that therefore affect either shadow wages (e.g. Singh, Squire, and Strauss, 1986) or actual wages within the household. As returns to labor for households in developing countries are affected by agricultural self-employment, which is difficult to accurately value, good proxies include both individual demographic characteristics and household characteristics. From the household perspective, such variables include the household demographic composition and household head's human capital. These variables are all measured prior to migration, so migration does not cause changes in values of those variables between surveys.

In a pure labor supply model, income or wealth should not affect migration decisions, since theoretically individual labor supply should only depend upon the returns to labor across potential jobs. Local characteristics at the migration source can affect the local returns to labor, which then affect migration decisions. For example, the relative returns to labor both within and outside agriculture may affect

\footnotetext{
${ }^{4}$ Because international migration is often more costly, it is not typically pro-poor, as the poor are less able to pay migration costs (e.g. McKenzie, 2007). As a result, evidence shows that relatively poor migrants are more likely to move to closer countries or those with lower transaction costs (e.g. Abramitsky et al., 2012). To overcome the credit constraint, an outcome has been the explicit recruitment of laborers by companies representing places with labor shortages (e.g. Beam, 2016; ILO, 2017).
} 
migration decisions, since higher local returns to labor reduce the incentives to migrate, while lower returns to labor would increase the incentives to migrate. Still, youth might respond differently to variables proxying for returns to labor than older workers. As discussed above, migration may require either credit or liquidity to pay for moving or search costs associated with job search. If credit markets are incomplete, then measures of wealth, income, or even income shocks play a role in determining migration, since they proxy for households that can afford to migrate (Halliday, 2006; Bazzi, 2017).

Based on this discussion, the basic model of migration estimated in this paper relates migration, $M$, by individual $i$ in household $h$ from village $v$ in region $r$ to individual characteristics, $X$, household demographic variables, $Z$, wealth variables, $C$, and local area characteristics $A$ :

$M_{i h r}=f\left(X_{i h v r}, Z_{h v r}, C_{h v r}, A_{v r}, \delta_{r}\right)$

where $\delta_{r}$ represents regional characteristics that might also shape returns to migration. The empirical section describes the model in more detail.

\section{Data}

To study determinants of rural youth migration, large multi-topic data sets are the best fit (e.g. Living Standards Measurement Surveys). Ideally, surveys to be used are also nationally representative of rural areas; two of the surveys used in this paper are not nationally representative, but cover much of each country. ${ }^{5}$ However, not all multi-topic surveys ask questions about migration behavior among household members, so the paper is limited to using a subset of the multi-topic surveys that exist. ${ }^{6}$

The paper uses five large data sets that all have at least two recent survey rounds in which it is possible to track individuals between surveys (Table 1 ). The surveys were collected either by the RAND Labor and Population Program (Indonesia), the International Food Policy Research Institute (Bangladesh and Pakistan), or are part of the Living Standards Measurement Surveys Integrated Surveys on Agriculture

\footnotetext{
${ }^{5}$ Two of the panel surveys used are not nationally representative of rural areas. The Indonesia Family Life Survey (IFLS) is nearly representative (Strauss et al., 2009; Strauss, Witoelar, and Sikoki, 2016), and the Pakistan Rural Household Panel Survey (PRHPS) is representative of rural areas of the three provinces in which it was collected (IFPRI and IDS, 2014).

${ }^{6}$ Furthermore, the data set needs to be large enough to have enough migrants for statistical analysis; the Malawi LSMS-ISA surveys, for example, did not identify a large enough number of youth migrants between rounds to include in the paper.
} 
managed by the World Bank (Nigeria and Tanzania). ${ }^{7}$ Panel surveys are useful in this context because they can be used to make inferences about migration flows, rather than just considering whether or not households have access to a migrant who left earlier, and can be thought of as part of the migrant stock from that area. In each survey used, migrants were either physically tracked or the survey form specifically asked about their whereabouts. Finally, the individuals are coded so that they fit the definition of youth in the end survey, not the initial survey.

Migration can be broadly defined as individuals who both move away from the village and away from the source household between the first and second survey. Particularly among youth, a substantial number of those moving out of the village do so to start a new household elsewhere; only the Indonesia and Tanzania surveys attempted to track migrants and interview their new households. Of course, people might move for multiple purposes; e.g. to work for a salary, get married, and set up a new household. As all the surveys include a question about why individuals moved out of households, this question is used to split migration into a "broad" and a "narrow" rationale for migration. The broad migration definition includes those who moved out of the source household and left for any reason; the narrow definition attempts to better isolate those who may have primarily moved to work, by removing those who stated the primary reason was to start a new household, get married, or get divorced. ${ }^{8}$

By the broad migration measure, the number of migrants who leave households between surveys varies substantially by country, as does the gender composition of those moving (Table 1). Youth migration rates vary from 7.5 percent in Bangladesh to 20 percent in Indonesia (Panel A); in all countries but Bangladesh, more female youth move out of households than males. Migration rates are lower for narrow migration, and the gender ratio flips for every country except Tanzania. The same is not true among young adults (Panel B); in all countries but Tanzania, young adult migrants are always more likely to be male.

The probability that any individual has migrated generally varies by age within those who are considered youth. In panel surveys, the probability of migration is typically quite low among younger people and rises among older cohorts (Figure 1). In some countries, it falls again for older cohorts; specifically, this pattern is clear in Bangladesh and Indonesia. In Indonesia, the probability rises relatively rapidly, while in other

\footnotetext{
${ }^{7}$ The three remaining data sets used are the Bangladesh Integrated Household Survey (BIHS), collected in 2011 and 2015 by IFPRI (Ahmed, 2013), the Nigeria General Household Survey (from 2013 and 2016), and the Tanzania National Panel Survey (from 2008 and 2013); the latter two were collaboratively collected by the respective national statistical organizations and the World Bank.

${ }^{8} \mathrm{~A}$ second major reason often given to migrate is for schooling, but such migrants often find opportunities to work thereafter and remain away from the household.
} 
countries it rises more slowly; in most countries, the probability plateaus around age 20 , though in Nigeria the probability appears to continue to rise as individuals are older. From the perspective of age, the propensity to migrate differs substantially by country.

Next, we explore whether youth and young adult migrants have different human capital characteristics than non-migrants; specifically, we measure whether those who leave households in general are more likely to be a child of the household head, whether they are more likely to be married by the endline, and their years of schooling (Table 2). In the first survey, if children were not children of the household head, most frequently they were a niece or nephew, or a grandchild of the head. Among youth, in Tanzania, Nigeria, and Indonesia, children of household heads are slightly less likely to migrate, whereas they are more likely to migrate in Bangladesh and there is no difference in averages in Pakistan. Due to the broad definition of youth migration used here, migrants are generally more likely to be married than nonmigrants; however, it does not hold for Indonesia and Pakistan; in the latter, marriage rates among youth appear notably low in general.

Among young adults, more children-in-law of household heads will have moved in, so migrants are more likely to be children of the head (but only marginally so in Indonesia and Tanzania). Migrants are typically less likely to be married, perhaps due to the presence of in-laws.

Finally, in most countries, migrants appear to be more educated than non-migrants among both youth and young adults. This finding is expected, as in most contexts migration for labor is positively selected. In Indonesia, average education levels appear about the same, and in Pakistan youth migrants are less educated than non-migrants. Both findings are likely a result of the relative share of migrants for family reasons rather than for explicitly economic reasons.

\section{Determinants of Youth Migration Flows}

In this section, the goal is to understand what variables are correlated with migration from households, by country. An expectation is that those determinants will vary somewhat by country. The goal of this exercise is to understand better what types of characteristics lead to migration and whether general patterns emerge even across very different contexts.

To initially consider whether wealth plays a role in the propensity to migrate among youth, for the four panel countries available, migration is plotted against the logarithm of per capita household consumption. Per capita consumption is measured at baseline, and Figures 2 and 3 use the broad and narrow definitions 
of migration, respectively. The plots by country are very different, suggesting that the relationship between migration and wealth differs substantially by country. Using the broad definition, in the two South Asian countries the poor are more likely to migrate than those with higher incomes; however, in Bangladesh the probability also turns positive at higher consumption levels. In the two African countries, there appears to be a positive relationship in Nigeria, suggesting potential credit constraints, and no relationship in Tanzania.

There are several differences between the broad and narrow definitions of migration (Figure 3). In Pakistan and Tanzania, there still appears to be little relationship between migration and consumption. On the other hand, in Nigeria and in Bangladesh there appears to be higher migration among the poor. In Nigeria, the propensity to migrate rises again among better off households. In general, these figures suggest that credit constraints do not appear to bind for youth migration in any of these settings.

\section{Relative Deprivation}

An alternative hypothesis is that it is not wealth or well-being in absolute terms that matters to migration, but rather relative well-being. As discussed in the introduction, relative deprivation may affect migration, where following Stark and Taylor (1991) the relative deprivation of household $i$ is defined as:

$R D_{i}=\int_{y_{i}}^{y_{h}} g(1-F(x)) d x$

where $y_{h}$ is the highest comparison expenditure level; here, the enumeration area is used as the comparison group. Note that the wealthiest household, in terms of consumption, will have a relative deprivation measure of zero, so poorer households within enumeration areas appear to the right of the graph. As a result, the measure is not exactly a ranking, as the cumulative amount of consumption by all richer households in the sample matters to the measure, so a high relative deprivation measure implies that other households in the enumeration area are much better off. Finally, because there is not an instrument available for relative deprivation, any results related to relative deprivation should not be considered causal.

The results of this exercise demonstrate that relative deprivation may be correlated with youth migration in the sub-Saharan African countries, but not in the South Asian ones (Figures 4 and 5). In both South Asian countries, a flat line can easily be drawn through the confidence interval for both broad and narrow migration. However, particularly for the narrow migration measure, in both Nigeria and Tanzania the probability of migration turns up at high levels of the measure, whereas the measure is otherwise flat. Therefore, relative deprivation may have a highly non-linear relationship with migration in those 
countries. Note that the measure is likely noisy, and the framework is not multivariate, so this hypothesis deserves further attention later in the paper.

\section{Multivariate Determinants of Migration}

As discussed in the conceptual framework, individual characteristics, household demographics, and wealth are hypothesized to potentially affect migration. To ensure that similar strategies can be used to measure variables that affect migration, depending upon the definition, equation (1) is initially linearized:

$M_{i h v r}=\alpha_{v r}+\beta X_{i h v r}+\rho Z_{h v r}+\delta C_{h v r}+u_{i h v r}$

Equation (3) includes four broad sets of explanatory variables. ${ }^{9}$ First, individual-level characteristics, including gender, age (in years), and schooling level are included, as well as whether the individual is a child of the household head. The former two variables are measured in the last survey round, to ensure that schooling is as complete as possible. Second, household demographic characteristics are included to proxy for wage rates within the household. These variables include household size, the share of the household that is female, the share of the household categorized as youth, the share that is under 5 , and the share that is elderly. The former two variables might hinder youth migration, because their presence likely ties up more of the household's time for additional care. Household demographic variables also include household head characteristics, include gender, age, and indicators for a lack of education and at least completion of a primary education. All these variables are measured at baseline or pre-migration. Third, a set of asset indicators are included, again measured at baseline.

\section{Main Results, Youth Migration Flows}

The broad youth migration variable was initially regressed on the three sets of explanatory variables (Table 3). A few results are broadly consistent across countries. First, women appear more likely to migrate in most countries; this result is likely due to the inclusion of marriage as a potential reason for migration. In four of the five countries, youth who are older are more likely to migrate; this result is consistent with Figure 1. Among individuals, higher education levels, including whether secondary school was completed, or higher levels that secondary were at least attempted, are significant predictors of migration in all five countries. The latter result may be linked to the fact that this variable was measured at endline, and some of the individuals characterized as youth may have moved specifically to attend school elsewhere, at least

\footnotetext{
${ }^{9}$ In estimation, all regressions control for enumeration area fixed effects and standard errors are clustered at the village or enumeration area level. Regressions are estimated using the linear probability model.
} 
initially. ${ }^{10}$ Being a child of the household head, meanwhile, has conflicting results by country, though is often statistically associated with youth migration. In South Asia (Bangladesh and Pakistan), coefficients are positive, whereas in Indonesia and Tanzania, they are negative. In Tanzania in particular, it may be that children who are taken care of by the head through adolescence are nudged out of the household after they reach early adulthood.

Fewer of the household demographic variables are consistently correlated with migration by household members. Larger households are more likely to send out migrants in Bangladesh and Indonesia; households with more women as a share of the households are also more likely to send out migrants in Pakistan. In Bangladesh and Nigeria, the share of household that are under 5 is negatively correlated with migration, suggesting that the time allocation may be more constrained in such households. In several countries, the share of youth in the household at baseline is negatively correlated with future migration; however, that coefficient may reflect the fact that youth migration is defined by the age at endline in this context, so demographically there may be fewer youth in those households at baseline.

Finally, the three asset indicators do not suggest that internal youth migration flows are affected by credit constraints. If anything, there is evidence of the opposite; households with fewer consumption goods appear to be more likely to send out migrants in several countries. In three of the five countries, households with no major consumer durables are more likely to send out migrants; in Pakistan, ownership of the family house is negatively correlated with youth migration. Consistent with the descriptive evidence in Figures 2 and 3, credit or liquidity constraints do not appear to affect youth migration from rural areas.

When migration is limited to the narrow definition, results are quite similar to the broader definition, with one clear exception (Table 4). The gender results in Table 3 are reversed with the narrow definition, better matching the hypothesis that males are more likely to leave for labor migration than females; in four of the five countries, the coefficient is positive, and quite large in Bangladesh and Indonesia (12 and 6.5 percentage points, respectively). Other results are either muted or similar to those for the broader migration variable. For example, household size is only a significant predictor of migration in Nigeria; in this case, larger households are less likely to have sent out migrants presumably for work, though the coefficient is small.

\footnotetext{
${ }^{10}$ Note that the "more than secondary school" variable was dropped in Bangladesh, because only two sample youth had more education than completing secondary school.
} 
A second important comparison is with young adult migration, using the broad (Table 5) and narrow (Table 6) definitions. There are several interesting differences between determinants of youth and young adult migration, mainly focused on individual characteristics. First, age no longer acts as a determinant in most countries among 25-34 year olds, unlike the finding in Tables 3 and 4. Second, with the exception of Tanzania, schooling levels are not an important determinant of migration, whereas they were important among youth in several countries. Third, being a child of the household head is a positive determinant in three countries and a negative determinant in the fourth (Indonesia), whereas it was not significant as a determinant in three of the five countries for youth migration. While it is difficult to generalize due to the mixed results, it could be that children of the head who had not formed their own household by age 25 become more likely to migrate in some countries. Other results are reasonably similar; for example, again there are no clear correlations with asset holdings.

\section{Credit Constraints and Relative Deprivation}

Next, the data are used to test whether youth or young adult migration is affected by either credit constraints or relative deprivation. In particular, with the data sets compiled for this paper, it is possible to test the relative deprivation hypothesis in a much broader sense than previous literature. ${ }^{11}$ For these tests, equation (3) is re-estimated without the asset variables and using the narrow migration measure as the dependent variable. Sequential regressions are estimated including a variable for the logarithm of baseline household consumption and relative deprivation at baseline on the right-hand side.

The hypotheses are tested in Table 7 by country and by migrant age category. In two of the three Asian countries there is a negative relationship, statistically significant at the 5 percent level, between youth migration flows and consumption (Panel A), suggesting again that credit constraints are not binding, and the relatively poor are more likely to seek employment outside the village, holding other factors constant. Only the point estimate in Nigeria is positive. Similarly, credit constraints do not appear to bind among young adult migrants; the coefficient is again statistically different from zero in Bangladesh, and is only positive in Tanzania. If anything, migration should have increased consumption in the cross-section at the

\footnotetext{
${ }^{11}$ For example, the Stark and Taylor (1991) paper uses 423 observations in total, and their statistical analysis does not account for the sample design. Recently, Benfica, Kafle, and Winters (2018) study migration and relative deprivation in sub-Saharan Africa, but use a stock measure of migration, do not focus on youth migration, and though they generally find a positive relationship, there is a remaining concern about potential reverse causality in their analysis.
} 
origin, so the coefficient is potentially positively biased, against binding credit constraints. Therefore, credit constraints do not appear to bind on youth or young adult migration in these countries.

Further, there appears to be no correlation between relative deprivation and youth migration, somewhat contradicting previous studies. None of the coefficients is statistically different from zero. ${ }^{12}$ Therefore, it is not clear that relative deprivation plays a major role in youth or young adult migration.

\section{Village Level Determinants}

Finally, village level determinants are examined for both youth and young adult migration (Table 8), again using the narrow definition. Land availability only appears to affect migration in some countries once we hold constant individual and household determinants of migration. Point estimates are particularly small among youth migrants. Similarly, there are only a few countries for which the share of households with a worker listing off-farm work as their main occupation. It may be that for most potential migrants, offfarm opportunities are so limited that they do not hinder migration. This point could be less binding for the Bangladeshi and Indonesian economies, where significant negative coefficients were found among youth and young adults, respectively. Third, we only find one significant coefficient for population density; the youth are less likely to leave more densely populated areas in Indonesia. Finally, we find a positive coefficient for the enhanced vegetation index only in Nigeria among young adult migrants; it does not appear to be correlated with youth migration. In sum, village-level correlations seem scattered and lack clear patterns, but those significant correlations found among both youth and young adults are consistent with theory.

\section{Summary}

In general, the examination of determinants of migration across several countries demonstrates some common lessons. First, individual characteristics of youth are important determinants of migration, relative to other potential variables that might shape returns to labor within the household. Youth become more likely to migrate with age, though in some countries the propensity to migrate levels off by age 23 or 24 according to descriptive statistics. The relationship between gender and youth migration propensity substantially depends on the migration definition (Tables 3 and 4); the same is not true for young adult migration (Tables 5 and 6). Finally, consistent with the literature higher levels of education are positively correlated with migration everywhere except Tanzania. Finally, from a national perspective, in the

\footnotetext{
${ }^{12}$ The relative deprivation variable is measured as $\log (X+1)$ where $X$ is relative deprivation, as the measure is zero for the observation with the highest expenditures in each enumeration area. Dropping these observations and specifying as $\log (X)$ does not affect this conclusion.
} 
countries described here, credit constraints do not appear to affect migration; if anything, youth from relatively poor have more propensity to migrate (Table 7).

\section{Conclusion}

Rural youth are in the process of making decisions that substantially affect their life course. One set of decisions that young men and women relate to is migration. If they decide to migrate away from home and their home village, they make decisions about where to go, whether to leave the country or not, potentially for how long to go, and if and when to return. These decisions have implications for their life course, for the members of their source household, and for policy related to migration.

This paper studies the determinants of different types of migration by youth from five countries in Africa (Nigeria and Tanzania), and Asia (Bangladesh, Indonesia, and Pakistan). Empirical results suggest that youth mobility is more related to individual characteristics such as gender, age, and educational attainment, are more important than household demographics or asset holdings in determining the propensity to migrate. The latter variable is quite consistent with the literature on youth migration specifically and migration in general as well; more educated men and women are both more likely to migrate internally in four of the five countries studied.

The data presented in this paper are somewhat at odds with the literature, which suggest credit constraints hinder both internal and international migration. Two recent randomized control trials suggest migration from poor areas increases by relaxing that constraint (Bryan et al., 2014; Cai, 2018). However, both of these experiments were conducted in poor, remote areas; the data used in this paper studying internal migration are all at least regionally representative of rural areas, and such areas would make up a small share of the data in any given country, since poor, remote areas typically have lower population density. Hence, it may be that internal migration is only very locally credit constrained.

From a policy perspective, there are specific ways that migration can be fostered for policy objectives (e.g. Clemens et al., 2018). An obvious constraint is data availability; more and improved data on migration, particularly in combination with data on household expenditures, can help policy makers tailor migration policy to ensure it both reduces poverty and maintains productivity (de Brauw and Carletto, 2012). Nonetheless, the types of policies that can strengthen benefits of migration in the short term would appear similar to polices that generally support youth employment (e.g. Filmer et al., 2014). From the perspective of migration, improvements to roads and communication infrastructure can help reduce the costs of finding employment away from and being away from home. 
As the literature largely demonstrates migration is poverty reducing, policies that help foster positive outcomes from either internal or international migration may be quite cost-effective ways to reduce rural poverty. For example, investments in secondary cities or towns may be particularly beneficial, since available evidence suggests that poorer migrants tend to move to destinations that are closer to home (Ingelaere et al., 2017; Christiaensen et al., 2018). Improving access to technical and/or vocational education can also help young potential migrants find employment in sectors already in demand. Social protection can also potentially reduce risks, but only if payments are portable to the destination, as existing evidence from Mexico show no effects of social protection on domestic migration (Stecklov et al., 2005; Angelucci, 2012).

In India and Ethiopia, large rural public works programs (MGNREGA and PSNP) have been implemented to provide jobs in rural areas; an obvious question is whether guaranteed labor schemes affect rural-urban migration. ${ }^{13}$ Evidence suggests that MGNREGA reduces short-term migration from rural areas (Imbert and Papp, 2017). However, Muralidharan, Niehaus, and Sukhtankar (2016) find no effects on migration in Andhra Pradesh, and there are no clear studies of longer-term migration. In Ethiopia, there is little evidence related to impacts of PSNP on migration; Hoddinott and Makesha (2017) suggest that young women become less likely to migrate when households receive work from the PSNP, but not other household members. In sum, evidence is mixed that large public works programs, meant to create rural employment, have large effects on migration.

Finally, an important implication of this paper is that policy recommendations must be context specific, taking migration into account as a factor that changes the agricultural labor force and therefore potentially production. As youth migrate out of rural areas, the remainder of the agricultural labor force changes in both gender and skill composition, depending upon the destination of migrants, the gender composition of migrants, and the level of educational attainment. These attributes clearly differ substantially by country, and are therefore important factors in determining ways to support or promote specific types of agricultural production.

\footnotetext{
${ }^{13}$ MGNREGA stands for the Mahatma Gandhi National Rural Employment Guarantee Scheme and PSNP stands for the Productive Safety Net Programme.
} 


\section{References}

Abramitsky, Ran, Leah Boustan, and Katherine Eriksson, 2012. "Europe's Tired, Poor, Huddled Masses: Self-Selection and Economic Outcomes in the Age of Mass Migration," American Economic Review 102(5): 1832-1856.

Ahmed, Akhter, 2013. Bangladesh Integrated Household Survey (BIHS) 2011-2012. Washington, DC: International Food Policy Research Institute (dataset).

Akram, Agha Ali, Shyamal Chowdhury, and Ahmed Mushfiq Mobarak. 2017. "Effects of Emigration on Rural Labor Markets," NBER Working Paper no. 23929.

Angelucci, Manuela, 2012. "Conditional Cash Transfer Programs, Credit Constrains, and Migration," Labour 26(1): 124-136.

Bazzi, Samuel. 2017. "Wealth Heterogeneity and the Income Elasticity of Migration," American Economic Journal: Applied Economics 9(2): 219-255.

Beam, Emily. 2016. "Do job fairs matter? Experimental Evidence on the Impact of Job-Fair Attendance," Journal of Development Economics 120: 32-40.

Bosetti, Valentina, Cristina Cattaneo, and Giovanni Peri, 2018. "Should they stay or should they go? Climate Migrants and Local Conflicts," NBER Working Paper no. 24447.

Bryan, Gharad, Shyamal Chowdhury, and A. Mushfiq Mobarak. 2014. "Under-investment in a Profitable Technology: The Case of Seasonal Migration in Bangladesh," Econometrica 82(5): 1671-1748.

Cai, Shu, 2018. "Migration under Liquidity Constraints: Evidence from Randomized Credit Access in China," Journal of Development Economics, in press.

Carrington, William, Enrica Detragiache, and Tara Vishnawath, 1996. "Migration with Endogenous Moving Costs," American Economic Review 86(4): 909-930.

Christiaensen, Luc, Joachim de Weerdt, Bert Ingalaere, and Ravi Kanbur, 2018, "Migrants, Towns, Poverty, and Jobs: insights from Tanzania," World Bank Policy Research Working Paper no. 8340.

Clemens, Michael, Cindy Huang, Jimmy Graham, and Kate Gough, 2018. Migration is What You Make It: Seven Policy Challenges That Turned Challenges into Opportunities. Center for Global Development: Washington, DC.

Cincotta, Richard, Robert Engelman, and Danielle Anastasion, 2003. "The Security Demographic: Population and Civil Conflict After the Cold War," Population Action International: Washington, DC.

Cortes, Patricia, and Jessica Pan, 2013. "Outsourcing Household Production: Foreign Domestic Workers and Native Labor Supply in Hong Kong," Journal of Labor Economics 31(2): 327-371.

de Brauw, Alan, and Gero Carletto, 2012, "Improving the Measurement and Policy Relevance of Migration Information in Multi-Topic Household Surveys," electronically published by World Bank.

de Brauw, Alan, and John Giles, 2017. "Migrant Opportunity and the Educational Attainment of Youth in Rural China," Journal of Human Resources 52(1): 272-311. 
de Janvry, Alain, Kyle Emerick, Marco Gonzalez-Novarro, and Elizabeth Sadoulet, 2015. "Delinking Land Rights from Land Use: Certification and Migration in Mexico," American Economic Review 105(10): 3125-3149.

de Jong, Gordon, 2000. "Expectations, Gender, and Norms in Migrant Decision-Making," Population Studies 54: 307-319.

Filmer, Deon, Louise Fox, with Karen Brooks, Aparajita Goyal, Taye Mengistae, Patrick Premand, Dena Ringold, Siddharth Sharma, and Sergiy Zorya, 2014, Youth Employment in sub-Saharan Africa. World Bank: Washington, DC.

Glewwe, Paul, and Hanan Jacoby. 2004. "Economic Growth and the Demand for Education? Is there a Wealth Effect?" Journal of Development Economics 74(1): 33-51.

Halliday, Timothy, 2006. "Migration, Risk, and Liquidity Constraints in El Salvador," Economic Development and Cultural Change 54(4): 893-925.

Heckert, Jessica, 2015. "New Perspective on Youth Migration: Motives and Family Investment Pattern," Demographic Research 33(27): 865-900.

Hoddinott, John, and Tseday Mekasha, 2017. "Social Protection, Household Size and its Determinants: Evidence from Ethiopia." IFPRI Ethiopia Strategy Support Program Working Paper 107.

Imbert, Clement, and John Papp, 2017. "Short Term Migration, Rural Public Works, and Urban Labor Markets: Evidence from India," Journal of European Economic Association, forthcoming.

Ingelaere, Bert; Christiaensen, Luc; De Weerdt, Joachim; Kanbur, Ravi. 2017. "Why Secondary Towns Can Be Important for Poverty Reduction: A Migrant's Perspective." Policy Research Working Paper no. 8193. World Bank, Washington, DC.

International Food Policy Research Institute (IFPRI and Innovative Development Strategies (IDS), 2014. “Pakistan Rural Household Panel Survey 2012," https://doi.org/10.7910/DVN/28558, Harvard Dataverse V2.2.

International Fund for Agricultural Development (IFAD), 2019. 2019 Rural Development Report: Creating Opportunities for Rural Youth. IFAD: Rome.

International Labour Organization (ILO), 2017. The Migrant Recruitment Industry: Profitability and Unethical Practices in Nepal, Paraguay, and Kenya. Geneva: ILO.

Kafle, Kashi, Rui Benfica, and Paul Winters. 2018. "Does Relative Deprivation Induce Migration? Evidence from sub-Saharan Africa." IFAD Research Series Issue 21.

Kochar, Anjini. 2004. "Urban Influences on Rural Schooling in India." Journal of Development Economics 74(2004): 113-136.

McKenzie, David. 2007. "Paper Walls Are Easier to Tear Down: Passport Costs and Legal Barriers to Emigration." World Development 35, no. 11:2026-39.

Munshi, Kaivan. 2003. "Networks in the Modern Economy: Mexican Migrants in the U.S. Labor Market." Quarterly Journal of Economics 118(2): 549-99. 
Muralidharan, Karthik, Paul Niehaus, and Sundip Sukhtankar, 2016, "Building State Capacity: Evidence from Biometric Smartcards in India," American Economic Review 106(10): 2895-2929.

Rosenzweig, Mark, and Oded Stark. 1989. "Consumption Smoothing, Migration, and Marriage: Evidence from Rural India," Journal of Political Economy 97(4): 905-926.

Rosenzweig, Mark, and Chris Udry. 2014. "Rainfall Forecasts, Weather, and Wages in the Agricultural Cycle." American Economic Review 104(5): 278-283.

Singh, Inderjit, Lyn Squire and John Strauss, 1986. Agricultural Household Models: Extensions, Applications, and Policy. Baltimore, MD: Johns Hopkins University Press.

Stark, Oded, and David Bloom. 1985. "The New Economics of Labor Migration," American Economic Review 75(2): 173-178.

Stark, Oded, and J. Edward Taylor, 1991. "Migration Incentives, Migration Types: The Role of Relative Deprivation," Economic Journal 101 (408): 1163-1178.

Stecklov, Guy, Paul Winters, Marco Stampini, and Benjamin Davis, 2005. "Do Conditional Cash Transfers Influence Migration? A Study using Experimental Data from the Mexican PROGRESA Program," Demography 42(4): 769-790.

Strauss, John, Firman Witoelar, and Bondan Sikoki, and Anne Marie Wattie, 2009, "The Fourth Wave of the Indonesia Family Life Survey: Overview and Field Report." RAND.

Strauss, John, Firman Witoelar, and Bondan Sikoki, 2016. "The Fifth Wave of the Indonesia Family life Survey: Overview and Field Report." RAND.

Valentine, Jessa Lewis, Brad Barham, Seth Gitter, and Jenna Nobles, 2017, "Migration and the Pursuit of Education in Southern Mexico," Comparative Education Review 61(1): 000.

Yitzhaki, Shlomo. 1979. "Relative Deprivation and the Gini Coefficient," Quarterly Journal of Economics 93(2): 321-324. 

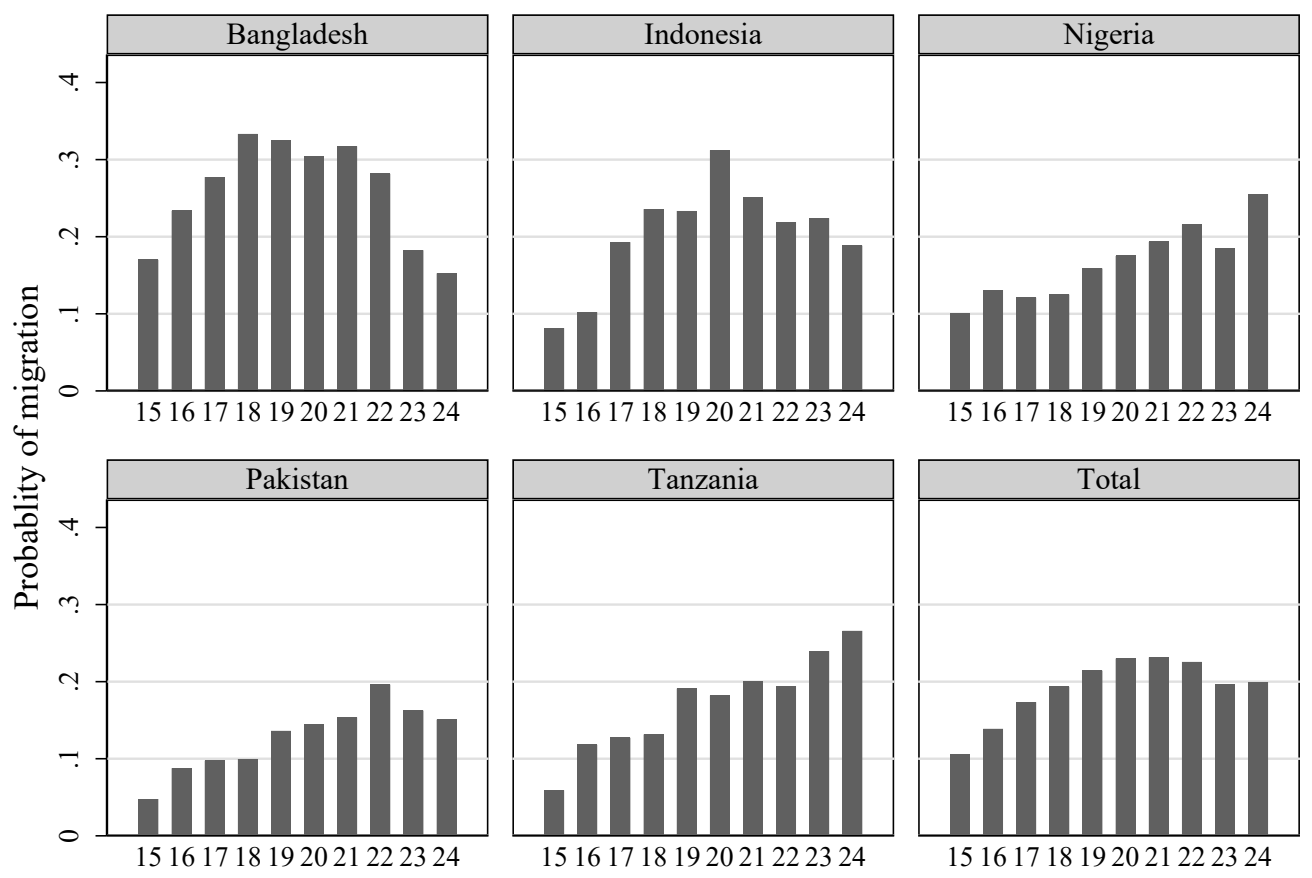

Graphs by country

Figure 1. Youth Migration Rates, by Age and Country, Panel Data 

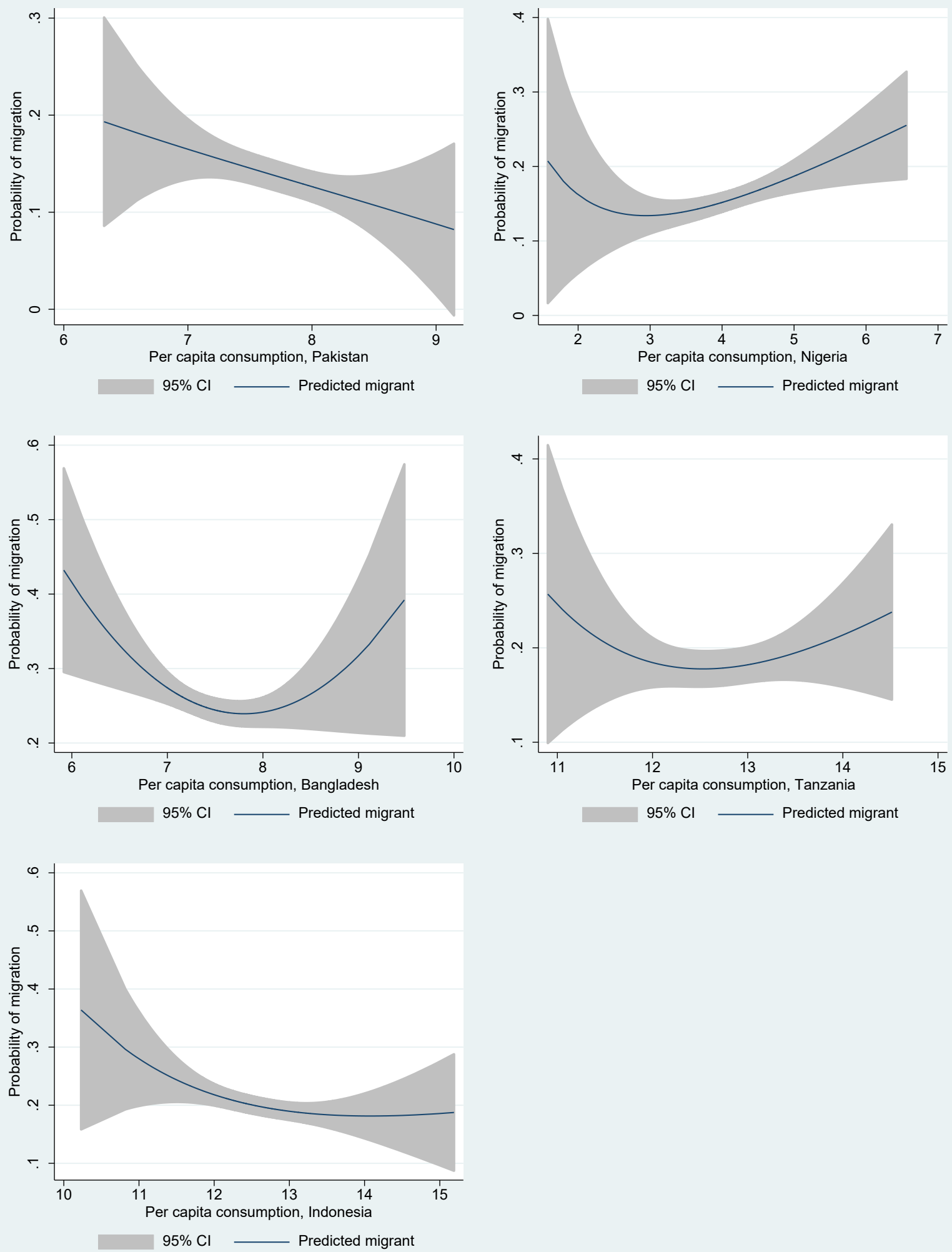

Figure 2. Relationship of Probability of Migration with Logarithm of Per Capita Consumption, by Country, Broad Definition of Migration 

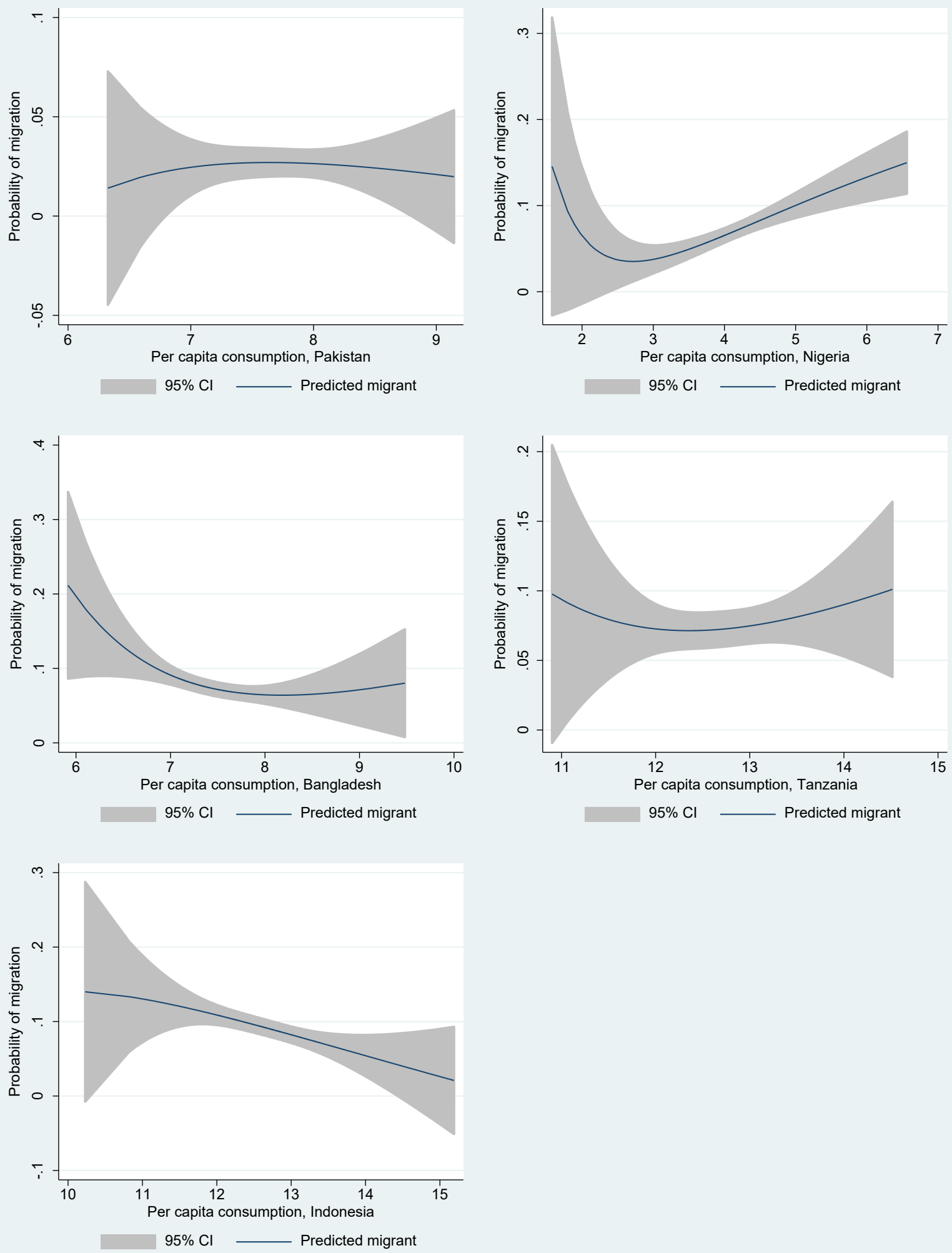

Figure 3. Relationship of Probability of Migration with Logarithm of Per Capita Consumption, by Country, Narrow Definition of Migration 

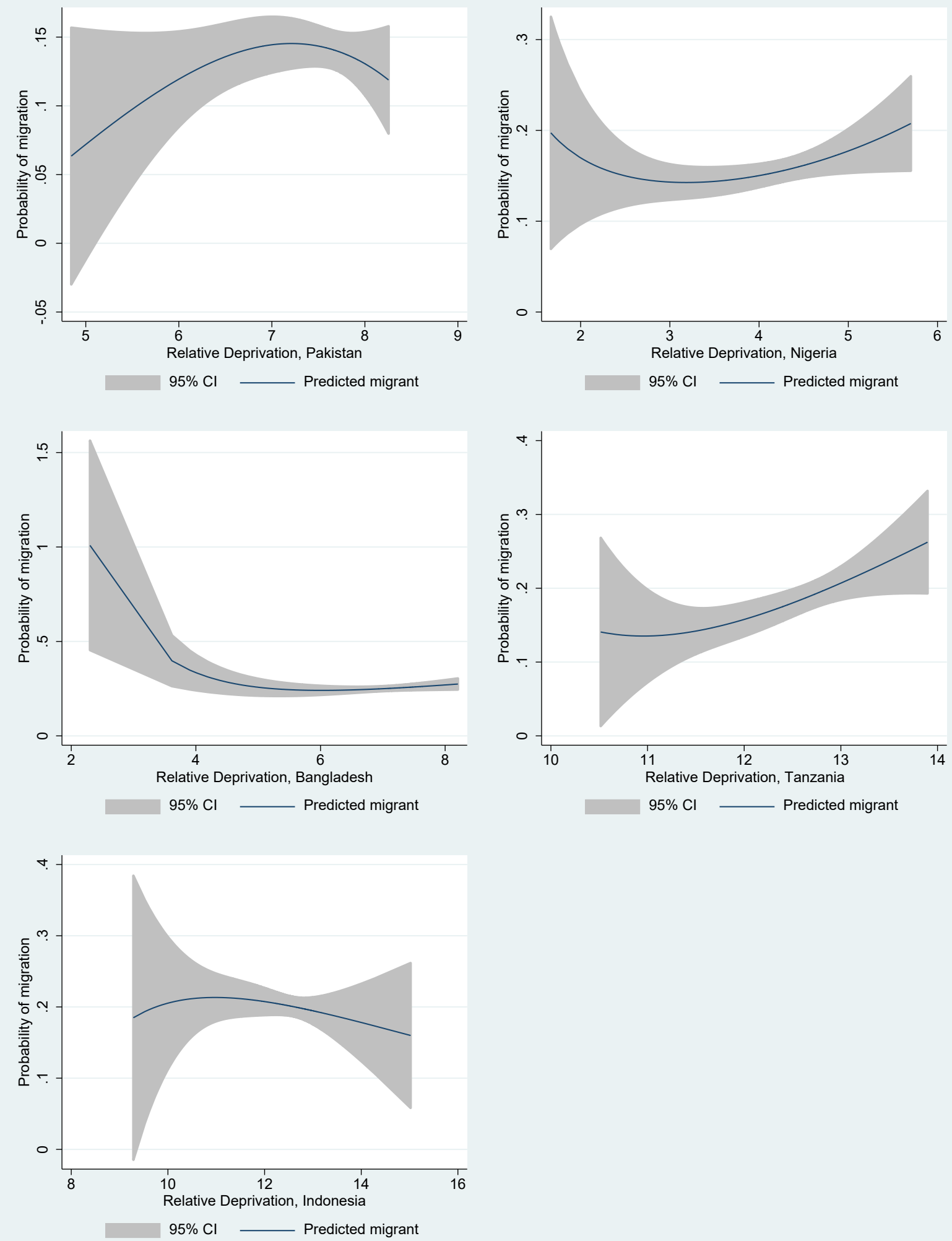

Figure 4. Relationship of Probability of Broad Definition of Migration with Logarithm of Relative Deprivation, by Country 

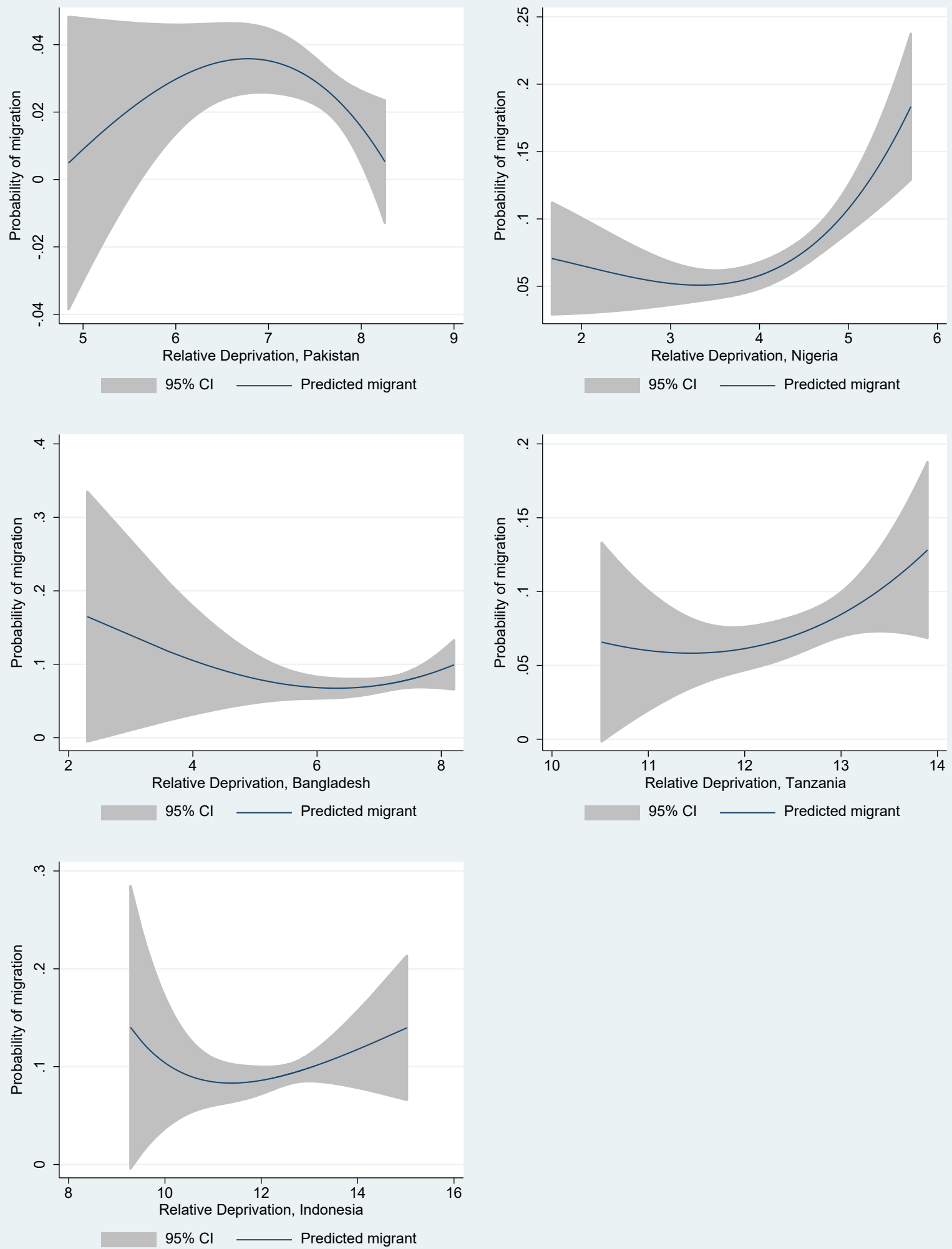

Figure 5. Relationship of Probability of Broad Definition of Migration with Logarithm of Relative Deprivation, by Country 
Table 1. Sample Size and Number of Migrants, by Definition, Panel Surveys

\begin{tabular}{|c|c|c|c|c|c|c|c|c|}
\hline \multirow{2}{*}{ Country } & \multirow{2}{*}{ Years } & \multirow{2}{*}{$\begin{array}{l}\text { Sample } \\
\text { size }\end{array}$} & \multicolumn{2}{|c|}{$\begin{array}{c}\text { Number of } \\
\text { Total Migrants }\end{array}$} & \multirow{2}{*}{$\begin{array}{l}\text { Percent } \\
\text { of } \\
\text { Sample, } \\
\text { Migrants }\end{array}$} & \multicolumn{2}{|c|}{$\begin{array}{c}\text { Number of } \\
\text { Narrow } \\
\text { Migrants }\end{array}$} & \multirow{2}{*}{$\begin{array}{c}\text { Percent } \\
\text { of } \\
\text { Sample, } \\
\text { Narrow } \\
\text { Migrants }\end{array}$} \\
\hline & & & Male & Female & & Male & Female & \\
\hline \multicolumn{9}{|c|}{ Panel A: 15 - 24 years, inclusive } \\
\hline Bangladesh & 2011-2, 2015 & 4293 & 363 & 726 & $25.4 \%$ & 276 & 49 & $7.6 \%$ \\
\hline Indonesia & 2007,2014 & 4061 & 453 & 369 & $20.2 \%$ & 254 & 119 & $9.2 \%$ \\
\hline Nigeria & 2013, 2016 & 4068 & 247 & 391 & $15.7 \%$ & 169 & 110 & $6.9 \%$ \\
\hline Pakistan & 2012, 2014 & 2833 & 121 & 265 & $13.6 \%$ & 66 & 8 & $2.6 \%$ \\
\hline Tanzania & $2008-9,2012-3$ & 2448 & 175 & 276 & $18.4 \%$ & 89 & 94 & $7.5 \%$ \\
\hline \multicolumn{9}{|c|}{ Panel B: 25 - 34 years, inclusive } \\
\hline Bangladesh & 2011-2, 2015 & 3524 & 192 & 88 & $8.0 \%$ & 183 & 35 & $6.2 \%$ \\
\hline Indonesia & 2008, 2014 & 4039 & 315 & 232 & $13.5 \%$ & 161 & 54 & $5.3 \%$ \\
\hline Nigeria & 2013, 2016 & 2203 & 188 & 159 & $15.8 \%$ & 121 & 41 & $7.4 \%$ \\
\hline Pakistan & 2012, 2014 & 1930 & 119 & 112 & $12.0 \%$ & 40 & 2 & $2.2 \%$ \\
\hline Tanzania & $2008-9,2012-3$ & 1238 & 88 & 139 & $18.3 \%$ & 65 & 60 & $10.1 \%$ \\
\hline
\end{tabular}

Sources: Bangladesh, BIHS 2011-2 and 2015; Indonesia, IFLS-4 and IFLS-5; Nigeria, NGHS 2013 and 2016;

Pakistan, PRHPS 2012 and 2014; Tanzania, TNPS 2008-9 and 2012-3. 
Table 2. Human Capital Characteristics, by Country and Migration Status, Panel Countries

\begin{tabular}{|c|c|c|c|c|c|c|}
\hline \multirow[b]{2}{*}{ Country } & \multicolumn{2}{|c|}{ Child of Head? } & \multicolumn{2}{|c|}{ Married? } & \multicolumn{2}{|c|}{ Years of Schooling } \\
\hline & Migrant & $\begin{array}{c}\text { Non- } \\
\text { Migrant }\end{array}$ & Migrant & $\begin{array}{c}\text { Non- } \\
\text { Migrant }\end{array}$ & Migrant & $\begin{array}{c}\text { Non- } \\
\text { Migrant }\end{array}$ \\
\hline \multicolumn{7}{|c|}{ Youth (15-24 Year Olds) } \\
\hline Bangladesh & 86.5 & 73.4 & 55.0 & 24.4 & 6.98 & 5.97 \\
\hline Indonesia & 56.8 & 65.5 & 30.9 & 29.1 & 9.54 & 9.79 \\
\hline Nigeria & 79.8 & 85.4 & See notes & 6.0 & 7.33 & 6.91 \\
\hline Pakistan & 78.7 & 79.5 & 12.4 & 12.7 & 4.15 & 4.80 \\
\hline Tanzania & 62.5 & 74.9 & 41.1 & 13.1 & 5.77 & 5.09 \\
\hline \multicolumn{7}{|c|}{ Young Adults (25-34 Year Olds) } \\
\hline Bangladesh & 50.7 & 17.7 & 14.6 & 88.4 & 6.77 & 5.51 \\
\hline Indonesia & 35.1 & 34.8 & 76.4 & 85.8 & 9.01 & 8.89 \\
\hline Nigeria & 73.8 & 35.8 & See notes & 62.3 & 8.98 & 6.50 \\
\hline Pakistan & 65.4 & 32.8 & 45.9 & 72.2 & 5.66 & 3.98 \\
\hline Tanzania & 34.4 & 27.7 & 63.9 & 76.6 & 5.81 & 5.15 \\
\hline
\end{tabular}


Table 3. Determinants of Youth Migration, Defined as Anyone Leaving Household for Elsewhere as Migrants, Panel Countries

\begin{tabular}{|c|c|c|c|c|c|}
\hline & Bangladesh & Indonesia & Nigeria & Pakistan & Tanzania \\
\hline \multicolumn{6}{|c|}{ Individual (Youth) Characteristics } \\
\hline Gender (1=male) & $\begin{array}{c}-0.163^{* * *} \\
(0.018)\end{array}$ & $\begin{array}{c}0.038^{* *} \\
(0.017)\end{array}$ & $\begin{array}{c}-0.096^{* * *} \\
(0.016)\end{array}$ & $\begin{array}{c}-0.072^{* * *} \\
(0.016)\end{array}$ & $\begin{array}{c}-0.088^{* * *} \\
(0.019)\end{array}$ \\
\hline Age & $\begin{array}{l}0.007^{*} \\
(0.004)\end{array}$ & $\begin{array}{c}0.016^{* * *} \\
(0.003)\end{array}$ & $\begin{array}{c}0.013^{* * *} \\
(0.003)\end{array}$ & $\begin{array}{c}0.020^{* * *} \\
(0.003)\end{array}$ & $\begin{array}{c}0.013^{* * *} \\
(0.004)\end{array}$ \\
\hline Less than Primary School & $\begin{array}{c}0.013 \\
(0.029)\end{array}$ & $\begin{array}{c}0.144^{* *} \\
(0.065)\end{array}$ & $\begin{array}{l}-0.018 \\
(0.024)\end{array}$ & $\begin{array}{l}-0.021 \\
(0.023)\end{array}$ & $\begin{array}{c}-0.084^{* *} \\
(0.036)\end{array}$ \\
\hline Primary School Complete & $\begin{array}{c}0.069 * * \\
(0.033)\end{array}$ & $\begin{array}{c}0.109 * * \\
(0.054)\end{array}$ & $\begin{array}{l}-0.007 \\
(0.025)\end{array}$ & $\begin{array}{l}-0.034^{*} \\
(0.018)\end{array}$ & $\begin{array}{l}-0.020 \\
(0.036)\end{array}$ \\
\hline Secondary School Complete & $\begin{array}{c}0.174^{* * *} \\
(0.046)\end{array}$ & $\begin{array}{c}0.156^{* * *} \\
(0.053)\end{array}$ & $\begin{array}{c}0.043 \\
(0.030)\end{array}$ & $\begin{array}{l}-0.043 \\
(0.028)\end{array}$ & $\begin{array}{c}0.073 \\
(0.055)\end{array}$ \\
\hline More than Secondary School & & $\begin{array}{c}0.186^{* * *} \\
(0.058)\end{array}$ & $\begin{array}{l}-0.007 \\
(0.057)\end{array}$ & $\begin{array}{c}-0.115^{* * *} \\
(0.036)\end{array}$ & $\begin{array}{c}0.707^{* * *} \\
(0.048)\end{array}$ \\
\hline Child of household head & $\begin{array}{c}0.163^{* * *} \\
(0.023)\end{array}$ & $\begin{array}{c}-0.035^{* *} \\
(0.015)\end{array}$ & $\begin{array}{c}0.001 \\
(0.024)\end{array}$ & $\begin{array}{c}0.048 * * \\
(0.023)\end{array}$ & $\begin{array}{c}-0.059 * * \\
(0.023)\end{array}$ \\
\hline \multicolumn{6}{|l|}{ Household Demographics } \\
\hline Household size & $\begin{array}{c}0.016^{* * *} \\
(0.005)\end{array}$ & $\begin{array}{c}0.003 \\
(0.005)\end{array}$ & $\begin{array}{l}-0.003 \\
(0.003)\end{array}$ & $\begin{array}{c}0.003 \\
(0.003)\end{array}$ & $\begin{array}{l}-0.001 \\
(0.004)\end{array}$ \\
\hline Share of Household, Female & $\begin{array}{c}0.053 \\
(0.057)\end{array}$ & $\begin{array}{l}-0.013 \\
(0.052)\end{array}$ & $\begin{array}{l}0.083^{*} \\
(0.049)\end{array}$ & $\begin{array}{c}0.158^{* * *} \\
(0.051)\end{array}$ & $\begin{array}{c}-0.006 \\
(0.071)\end{array}$ \\
\hline Share of Household, Youth & $\begin{array}{l}-0.023 \\
(0.047)\end{array}$ & $\begin{array}{c}-0.118^{* *} \\
(0.050)\end{array}$ & $\begin{array}{l}-0.096 * \\
(0.051)\end{array}$ & $\begin{array}{c}-0.093^{* *} \\
(0.037)\end{array}$ & $\begin{array}{l}-0.094 \\
(0.064)\end{array}$ \\
\hline Share of Household, under 5 & $\begin{array}{c}-0.297^{* * *} \\
(0.075)\end{array}$ & $\begin{array}{l}-0.034 \\
(0.084)\end{array}$ & $\begin{array}{c}-0.150^{* *} \\
(0.075)\end{array}$ & $\begin{array}{l}-0.054 \\
(0.068)\end{array}$ & $\begin{array}{c}0.004 \\
(0.094)\end{array}$ \\
\hline Age of household head & $\begin{array}{c}0.000 \\
(0.001)\end{array}$ & $\begin{array}{c}0.000 \\
(0.000)\end{array}$ & $\begin{array}{c}0.001 \\
(0.001)\end{array}$ & $\begin{array}{c}0.001 \\
(0.001)\end{array}$ & $\begin{array}{c}0.001 \\
(0.001)\end{array}$ \\
\hline $\begin{array}{l}\text { Gender of household head } \\
\text { (1=male) }\end{array}$ & $\begin{array}{l}-0.003 \\
(0.026)\end{array}$ & $\begin{array}{l}0.000 \\
(0.027)\end{array}$ & $\begin{array}{l}0.034 \\
(0.035)\end{array}$ & $\begin{array}{c}0.027 \\
(0.043)\end{array}$ & $\begin{array}{c}0.002 \\
(0.031)\end{array}$ \\
\hline Head has no education & $\begin{array}{l}0.035^{*} \\
(0.019)\end{array}$ & $\begin{array}{l}-0.006 \\
(0.032)\end{array}$ & $\begin{array}{l}-0.093 \\
(0.074)\end{array}$ & $\begin{array}{c}-0.161^{* * *} \\
(0.051)\end{array}$ & $\begin{array}{c}0.036 \\
(0.031)\end{array}$ \\
\hline $\begin{array}{l}\text { Head has primary school } \\
\text { education or more }\end{array}$ & $\begin{array}{l}0.015 \\
(0.025)\end{array}$ & $\begin{array}{l}-0.026 \\
(0.017)\end{array}$ & $\begin{array}{l}-0.026 \\
(0.017)\end{array}$ & $\begin{array}{l}-0.006 \\
(0.018)\end{array}$ & $\begin{array}{c}0.037 \\
(0.026)\end{array}$ \\
\hline Household Asset Holdings & & & & & \\
\hline Owns furniture? & $\begin{array}{l}-0.024 \\
(0.058)\end{array}$ & $\begin{array}{l}-0.090 \\
(0.080)\end{array}$ & $\begin{array}{l}-0.010 \\
(0.050)\end{array}$ & $\begin{array}{l}-0.008 \\
(0.021)\end{array}$ & $\begin{array}{l}-0.072 \\
(0.062)\end{array}$ \\
\hline Owns consumer durables? & $\begin{array}{c}-0.048^{* *} \\
(0.019)\end{array}$ & $\begin{array}{l}0.000 \\
(0.028)\end{array}$ & $\begin{array}{c}-0.045^{* *} \\
(0.018)\end{array}$ & $\begin{array}{l}-0.017 \\
(0.023)\end{array}$ & $\begin{array}{l}-0.043^{*} \\
(0.023)\end{array}$ \\
\hline Owns house? & $\begin{array}{c}0.001 \\
(0.044)\end{array}$ & $\begin{array}{l}-0.017 \\
(0.031)\end{array}$ & $\begin{array}{l}-0.049 \\
(0.047)\end{array}$ & $\begin{array}{l}-0.046^{*} \\
(0.024)\end{array}$ & $\begin{array}{l}-0.130^{*} \\
(0.074)\end{array}$ \\
\hline Number of observations & 3,497 & 3,983 & 3,826 & 2,798 & 2,370 \\
\hline R-squared & 0.137 & 0.206 & 0.212 & 0.109 & 0.219 \\
\hline
\end{tabular}

Notes: Standard deviations clustered at the enumeration area in parentheses, and enumeration area fixed effects included in all regressions. No observations in Bangladesh had more than secondary school education.

$* * * p<0.01, * * p<0.05, * p<0.1$.

Sources: Bangladesh, BIHS 2011 and 2015; Indonesia, IFLS-4 and IFLS-5; Nigeria, NGHS 2013 and 2016; Pakistan, PRHPS 2012 and 2014; Tanzania, TNPS 2008-9 and 2012-3. 
Table 4. Determinants of Youth Migration, Defined as Anyone Leaving Household for Non-Family Reasons, Panel Countries

\begin{tabular}{|c|c|c|c|c|c|}
\hline & Bangladesh & Indonesia & Nigeria & Pakistan & Tanzania \\
\hline \multicolumn{6}{|c|}{ Individual (Youth) Characteristics } \\
\hline \multirow[t]{2}{*}{ Gender (1=male) } & $0.117 * * *$ & $0.065 * * *$ & $0.021 * *$ & $0.040 * * *$ & -0.010 \\
\hline & $(0.012)$ & $(0.012)$ & $(0.010)$ & $(0.008)$ & $(0.014)$ \\
\hline \multirow[t]{2}{*}{ Age } & $0.009 * * *$ & $0.009 * * *$ & $0.008 * * *$ & $0.005^{* * *}$ & $0.010 * * *$ \\
\hline & $(0.003)$ & $(0.002)$ & $(0.002)$ & $(0.001)$ & $(0.003)$ \\
\hline \multirow[t]{2}{*}{ Less than Primary School } & 0.002 & 0.067 & 0.015 & 0.010 & $-0.068 * * *$ \\
\hline & $(0.024)$ & $(0.055)$ & $(0.015)$ & $(0.010)$ & $(0.026)$ \\
\hline \multirow[t]{2}{*}{ Primary School Complete } & 0.007 & 0.061 & 0.017 & 0.005 & $-0.076 * * *$ \\
\hline & $(0.024)$ & $(0.051)$ & $(0.015)$ & $(0.007)$ & $(0.026)$ \\
\hline \multirow[t]{2}{*}{ Secondary School Complete } & $0.070 * *$ & $0.108 * *$ & $0.054 * *$ & 0.017 & -0.057 \\
\hline & $(0.034)$ & $(0.052)$ & $(0.022)$ & $(0.011)$ & $(0.041)$ \\
\hline \multirow[t]{2}{*}{ More than Secondary School } & & 0.012 & 0.026 & $-0.026 * * *$ & $0.751 * * *$ \\
\hline & & $(0.054)$ & $(0.049)$ & $(0.010)$ & $(0.035)$ \\
\hline \multirow[t]{2}{*}{ Child of household head } & 0.007 & 0.012 & 0.005 & $0.021 * * *$ & $-0.045 * * *$ \\
\hline & $(0.015)$ & $(0.012)$ & $(0.016)$ & $(0.008)$ & $(0.017)$ \\
\hline \multicolumn{6}{|l|}{ Household Demographics } \\
\hline \multirow[t]{2}{*}{ Household size } & 0.004 & 0.001 & $-0.005^{* *}$ & -0.000 & 0.002 \\
\hline & $(0.003)$ & $(0.004)$ & $(0.002)$ & $(0.001)$ & $(0.002)$ \\
\hline \multirow[t]{2}{*}{ Share of Household, Female } & 0.001 & 0.011 & 0.016 & -0.006 & -0.034 \\
\hline & $(0.037)$ & $(0.040)$ & $(0.031)$ & $(0.023)$ & $(0.039)$ \\
\hline \multirow[t]{2}{*}{ Share of Household, Youth } & $-0.062 * *$ & -0.048 & 0.002 & 0.014 & -0.004 \\
\hline & $(0.029)$ & (0.039) & $(0.032)$ & $(0.016)$ & $(0.042)$ \\
\hline \multirow[t]{2}{*}{ Share of Household, under 5} & -0.028 & 0.001 & 0.016 & 0.041 & $-0.117^{*}$ \\
\hline & $(0.055)$ & $(0.053)$ & $(0.045)$ & $(0.030)$ & $(0.060)$ \\
\hline \multirow[t]{2}{*}{ Age of household head } & 0.000 & 0.000 & 0.001 & 0.000 & 0.000 \\
\hline & $(0.000)$ & $(0.000)$ & $(0.001)$ & $(0.000)$ & $(0.001)$ \\
\hline Gender of household head & -0.012 & -0.004 & 0.028 & 0.010 & 0.006 \\
\hline (1=male) & $(0.016)$ & $(0.020)$ & $(0.024)$ & $(0.026)$ & $(0.019)$ \\
\hline \multirow[t]{2}{*}{ Head has no education } & 0.018 & -0.017 & $-0.042 * *$ & -0.004 & 0.028 \\
\hline & $(0.012)$ & $(0.020)$ & $(0.021)$ & $(0.009)$ & $(0.020)$ \\
\hline Head has primary school & 0.002 & -0.011 & 0.011 & $0.016^{*}$ & 0.017 \\
\hline education or more & $(0.015)$ & $(0.013)$ & $(0.011)$ & $(0.008)$ & $(0.018)$ \\
\hline \multicolumn{6}{|l|}{ Household Asset Holdings } \\
\hline \multirow{2}{*}{ Owns furniture? } & -0.060 & $-0.139 *$ & -0.014 & -0.008 & -0.020 \\
\hline & $(0.044)$ & $(0.073)$ & $(0.028)$ & $(0.011)$ & $(0.042)$ \\
\hline \multirow[t]{2}{*}{ Owns consumer durables? } & $-0.020 *$ & -0.025 & -0.020 & 0.002 & -0.026 \\
\hline & $(0.011)$ & (0.019) & (0.013) & $(0.011)$ & (0.017) \\
\hline \multirow[t]{2}{*}{ Owns house? } & -0.008 & 0.003 & -0.034 & -0.019 & -0.057 \\
\hline & $(0.030)$ & $(0.022)$ & $(0.037)$ & $(0.013)$ & $(0.053)$ \\
\hline Number of observations & 3,497 & 3,983 & 3,826 & 2,798 & 2,370 \\
\hline $\mathrm{R} 2$ & 0.140 & 0.194 & 0.219 & 0.085 & 0.194 \\
\hline
\end{tabular}

Notes: Standard deviations clustered at the enumeration area in parentheses. Region level fixed effects included in all regressions. $* * * p<0.01, * * p<0.05, * p<0.1$.

Sources: Bangladesh, BIHS 2011 and 2015; Indonesia, IFLS-4 and IFLS-5; Nigeria, NGHS 2013 and 2016; Pakistan, PRHPS 2012 and 2014; Tanzania, TNPS 2008-9 and 2012-3. 
Table 5. Determinants of Young Adult (aged 25-34) Migration, Defined as Anyone Leaving Household, Panel Countries

\begin{tabular}{|c|c|c|c|c|c|}
\hline & Bangladesh & Indonesia & Nigeria & Pakistan & Tanzania \\
\hline \multicolumn{6}{|c|}{ Individual (Young Adult) Characteristics } \\
\hline \multirow[t]{2}{*}{ Gender (1=male) } & $0.041 * *$ & $0.072 * * *$ & -0.026 & -0.035 & -0.049 \\
\hline & $(0.019)$ & $(0.013)$ & $(0.026)$ & $(0.021)$ & $(0.031)$ \\
\hline \multirow{2}{*}{ Age } & -0.001 & $-0.011 * * *$ & -0.001 & $-0.006 *$ & -0.006 \\
\hline & $(0.003)$ & $(0.003)$ & $(0.003)$ & $(0.003)$ & $(0.006)$ \\
\hline \multirow[t]{2}{*}{ Less than Primary School } & 0.012 & 0.032 & -0.019 & 0.025 & -0.061 \\
\hline & $(0.013)$ & $(0.064)$ & $(0.033)$ & $(0.031)$ & $(0.043)$ \\
\hline \multirow[t]{2}{*}{ Primary School Complete } & -0.001 & 0.025 & -0.005 & 0.038 & 0.001 \\
\hline & $(0.018)$ & $(0.068)$ & $(0.030)$ & $(0.026)$ & $(0.036)$ \\
\hline \multirow[t]{2}{*}{ Secondary School Complete } & $0.065^{* *}$ & 0.047 & -0.009 & 0.012 & 0.018 \\
\hline & $(0.028)$ & $(0.067)$ & $(0.034)$ & $(0.031)$ & $(0.074)$ \\
\hline \multirow[t]{2}{*}{ More than Secondary School } & 0.061 & 0.020 & 0.056 & 0.231 & $0.710 * * *$ \\
\hline & $(0.072)$ & $(0.070)$ & $(0.056)$ & $(0.165)$ & $(0.128)$ \\
\hline \multirow[t]{2}{*}{ Child of household head } & $0.113^{* * *}$ & $-0.054 * * *$ & $0.147^{* * *}$ & $0.124 * * *$ & 0.022 \\
\hline & $(0.028)$ & $(0.015)$ & $(0.043)$ & $(0.031)$ & $(0.045)$ \\
\hline \multicolumn{6}{|l|}{ Household Demographics } \\
\hline \multirow[t]{2}{*}{ Household size } & 0.003 & 0.002 & $-0.004 * * *$ & -0.001 & 0.001 \\
\hline & $(0.003)$ & $(0.003)$ & $(0.002)$ & $(0.001)$ & $(0.002)$ \\
\hline \multirow[t]{2}{*}{ Share of Household, Female } & 0.010 & 0.006 & -0.010 & -0.003 & -0.027 \\
\hline & $(0.035)$ & $(0.032)$ & $(0.030)$ & $(0.021)$ & $(0.037)$ \\
\hline \multirow[t]{2}{*}{ Share of Household, Youth } & $-0.072 * *$ & $-0.081 * * *$ & -0.026 & 0.006 & -0.015 \\
\hline & $(0.028)$ & $(0.031)$ & $(0.032)$ & $(0.018)$ & $(0.037)$ \\
\hline \multirow[t]{2}{*}{ Share of Household, under 5} & -0.005 & 0.027 & -0.003 & 0.030 & -0.057 \\
\hline & $(0.051)$ & $(0.047)$ & $(0.046)$ & $(0.033)$ & $(0.051)$ \\
\hline \multirow[t]{2}{*}{ Age of household head } & 0.000 & 0.000 & $0.001 *$ & 0.000 & 0.000 \\
\hline & $(0.000)$ & $(0.000)$ & $(0.001)$ & $(0.000)$ & $(0.001)$ \\
\hline Gender of household head & -0.011 & -0.011 & 0.003 & -0.005 & 0.011 \\
\hline$(1=$ male $)$ & $(0.014)$ & $(0.016)$ & $(0.023)$ & $(0.022)$ & $(0.016)$ \\
\hline \multirow[t]{2}{*}{ Head has no education } & 0.017 & 0.006 & -0.040 & -0.003 & 0.007 \\
\hline & $(0.011)$ & $(0.020)$ & $(0.025)$ & (0.007) & $(0.017)$ \\
\hline Head has primary school & 0.002 & -0.015 & -0.004 & 0.014 & 0.009 \\
\hline education or more & $(0.014)$ & $(0.011)$ & $(0.010)$ & $(0.008)$ & $(0.016)$ \\
\hline \multicolumn{6}{|l|}{ Household Asset Holdings } \\
\hline \multirow[t]{2}{*}{ Owns furniture? } & -0.063 & -0.040 & -0.015 & $-0.045^{*}$ & -0.008 \\
\hline & $(0.043)$ & $(0.050)$ & $(0.060)$ & $(0.026)$ & $(0.078)$ \\
\hline \multirow[t]{2}{*}{ Owns consumer durables? } & 0.006 & -0.006 & -0.003 & -0.036 & -0.051 \\
\hline & $(0.014)$ & $(0.022)$ & $(0.028)$ & $(0.031)$ & $(0.034)$ \\
\hline \multirow[t]{2}{*}{ Owns house? } & 0.011 & $-0.041^{*}$ & 0.002 & 0.024 & -0.181 \\
\hline & $(0.021)$ & $(0.021)$ & $(0.053)$ & $(0.021)$ & $(0.134)$ \\
\hline Number of observations & 2,866 & 3,961 & 2,043 & 1,852 & 1,222 \\
\hline $\mathrm{R} 2$ & 0.172 & 0.214 & 0.254 & 0.141 & 0.338 \\
\hline
\end{tabular}

Notes: Standard deviations clustered at the enumeration area in parentheses. Region level fixed effects included in all regressions. $* * * \mathrm{p}<0.01, * * \mathrm{p}<0.05, * \mathrm{p}<0.1$.

Sources: Bangladesh, BIHS 2011 and 2015; Indonesia, IFLS-4 and IFLS-5; Nigeria, NGHS 2013 and 2016; Pakistan, PRHPS 2012 and 2014; Tanzania, TNPS 2008-9 and 2012-3. 
Table 6. Determinants of Young Adult (aged 25-34) Migration, Defined as Anyone Leaving Household, Panel Countries

\begin{tabular}{|c|c|c|c|c|c|}
\hline & Bangladesh & Indonesia & Nigeria & Pakistan & Tanzania \\
\hline \multicolumn{6}{|c|}{ Individual (Young Adult) Characteristics } \\
\hline \multirow[t]{2}{*}{ Gender (1=male) } & $0.097 * * *$ & $0.065 * * *$ & $0.056 * * *$ & $0.026 * * *$ & 0.008 \\
\hline & $(0.013)$ & $(0.009)$ & $(0.021)$ & $(0.008)$ & $(0.023)$ \\
\hline \multirow[t]{2}{*}{ Age } & -0.003 & -0.002 & -0.003 & -0.001 & 0.004 \\
\hline & $(0.002)$ & $(0.002)$ & $(0.002)$ & $(0.001)$ & $(0.004)$ \\
\hline \multirow[t]{2}{*}{ Less than Primary School } & 0.009 & 0.006 & $-0.052 * *$ & 0.007 & -0.006 \\
\hline & $(0.012)$ & $(0.048)$ & $(0.023)$ & $(0.012)$ & $(0.035)$ \\
\hline \multirow[t]{2}{*}{ Primary School Complete } & -0.007 & -0.011 & $-0.041 * *$ & 0.015 & 0.041 \\
\hline & $(0.016)$ & $(0.049)$ & $(0.019)$ & $(0.010)$ & $(0.027)$ \\
\hline \multirow[t]{2}{*}{ Secondary School Complete } & 0.018 & -0.013 & -0.013 & 0.013 & 0.092 \\
\hline & $(0.024)$ & $(0.048)$ & $(0.023)$ & $(0.012)$ & $(0.060)$ \\
\hline \multirow[t]{2}{*}{ More than Secondary School } & 0.061 & -0.039 & 0.033 & 0.045 & $0.675 * * *$ \\
\hline & $(0.072)$ & $(0.049)$ & $(0.041)$ & $(0.069)$ & (0.159) \\
\hline \multirow[t]{2}{*}{ Child of household head } & $0.045^{* *}$ & $-0.022 *$ & $0.060 * *$ & $0.034 * *$ & 0.005 \\
\hline & $(0.020)$ & $(0.012)$ & $(0.030)$ & $(0.014)$ & $(0.034)$ \\
\hline \multicolumn{6}{|l|}{ Household Demographics } \\
\hline \multirow[t]{2}{*}{ Household size } & 0.000 & 0.002 & -0.001 & 0.002 & -0.003 \\
\hline & $(0.004)$ & $(0.003)$ & $(0.002)$ & $(0.002)$ & $(0.003)$ \\
\hline \multirow[t]{2}{*}{ Share of Household, Female } & -0.019 & 0.005 & -0.032 & $-0.061 * * *$ & 0.057 \\
\hline & $(0.030)$ & $(0.026)$ & $(0.038)$ & $(0.023)$ & $(0.066)$ \\
\hline \multirow[t]{2}{*}{ Share of Household, Youth } & 0.004 & $-0.056 * * *$ & -0.052 & -0.017 & $0.174 * *$ \\
\hline & $(0.037)$ & $(0.021)$ & $(0.059)$ & $(0.018)$ & $(0.078)$ \\
\hline \multirow[t]{2}{*}{ Share of Household, under 5} & -0.024 & $-0.104 * * *$ & $-0.117 * *$ & 0.012 & 0.090 \\
\hline & $(0.030)$ & $(0.031)$ & $(0.052)$ & $(0.020)$ & $(0.077)$ \\
\hline \multirow[t]{2}{*}{ Age of household head } & 0.001 & 0.000 & 0.001 & $-0.001 *$ & 0.001 \\
\hline & $(0.001)$ & $(0.000)$ & $(0.001)$ & $(0.000)$ & $(0.001)$ \\
\hline Gender of household head & -0.002 & -0.007 & 0.057 & 0.035 & 0.001 \\
\hline$(1=$ male $)$ & $(0.017)$ & $(0.014)$ & $(0.038)$ & $(0.021)$ & $(0.043)$ \\
\hline \multirow[t]{2}{*}{ Head has no education } & -0.006 & 0.014 & 0.017 & -0.032 & -0.043 \\
\hline & $(0.012)$ & (0.019) & $(0.075)$ & (0.029) & $(0.037)$ \\
\hline Head has primary school & -0.002 & 0.007 & $0.034 * *$ & 0.002 & -0.021 \\
\hline education or more & $(0.014)$ & $(0.011)$ & $(0.016)$ & $(0.009)$ & $(0.031)$ \\
\hline \multicolumn{6}{|l|}{ Household Asset Holdings } \\
\hline \multirow[t]{2}{*}{ Owns furniture? } & -0.050 & 0.009 & -0.020 & -0.010 & -0.022 \\
\hline & $(0.043)$ & $(0.036)$ & $(0.035)$ & $(0.009)$ & $(0.063)$ \\
\hline \multirow[t]{2}{*}{ Owns consumer durables? } & 0.006 & -0.003 & -0.014 & -0.010 & -0.031 \\
\hline & $(0.013)$ & $(0.014)$ & $(0.017)$ & $(0.012)$ & $(0.028)$ \\
\hline \multirow[t]{2}{*}{ Owns house? } & 0.007 & $-0.027^{*}$ & 0.022 & 0.006 & -0.103 \\
\hline & $(0.020)$ & $(0.014)$ & $(0.032)$ & $(0.010)$ & $(0.081)$ \\
\hline Number of observations & 2,866 & 3,961 & 2,043 & 1,852 & 1,222 \\
\hline $\mathrm{R} 2$ & 0.170 & 0.196 & 0.242 & 0.116 & 0.295 \\
\hline
\end{tabular}

Notes: Standard deviations clustered at the enumeration area in parentheses. Region level fixed effects included in all regressions. $* * * \mathrm{p}<0.01, * * \mathrm{p}<0.05, * \mathrm{p}<0.1$.

Sources: Bangladesh, BIHS 2011 and 2015; Indonesia, IFLS-4 and IFLS-5; Nigeria, NGHS 2013 and 2016; Pakistan, PRHPS 2012 and 2014; Tanzania, TNPS 2008-9 and 2012-3. 
Table 7. Tests of Additional Hypotheses Related to Association between Credit Constraints and Relative Deprivation and Migration, Panel Countries

\begin{tabular}{|c|c|c|c|c|c|}
\hline \multicolumn{5}{|l|}{ Additional Explanatory Variable } & Tanzania \\
\hline \multicolumn{6}{|l|}{ Panel A: $15-24$ year olds } \\
\hline $\begin{array}{l}\text { Logarithm, per capita } \\
\text { consumption }\end{array}$ & $\begin{array}{c}-0.032 * * \\
(0.013)\end{array}$ & $\begin{array}{c}-0.030 * * * \\
(0.011)\end{array}$ & $\begin{array}{c}0.008 \\
(0.010)\end{array}$ & $\begin{array}{l}-0.001 \\
(0.009)\end{array}$ & $\begin{array}{l}-0.004 \\
(0.016)\end{array}$ \\
\hline Logarithm, relative deprivation & $\begin{array}{l}-0.001 \\
(0.003)\end{array}$ & $\begin{array}{c}0.002 \\
(0.002)\end{array}$ & $\begin{array}{l}-0.003 \\
(0.006)\end{array}$ & $\begin{array}{c}0.002 \\
(0.003)\end{array}$ & $\begin{array}{l}-0.001 \\
(0.002)\end{array}$ \\
\hline \multicolumn{6}{|l|}{ Panel B: 25-34 year olds } \\
\hline $\begin{array}{l}\text { Logarithm, per capita } \\
\text { consumption }\end{array}$ & $\begin{array}{c}-0.029 * * \\
(0.014)\end{array}$ & $\begin{array}{l}-0.008 \\
(0.008)\end{array}$ & $\begin{array}{l}-0.012 \\
(0.016)\end{array}$ & $\begin{array}{l}-0.002 \\
(0.010)\end{array}$ & $\begin{array}{c}0.027 \\
(0.025)\end{array}$ \\
\hline Logarithm, relative deprivation & $\begin{array}{c}0.004 \\
(0.003)\end{array}$ & $\begin{array}{l}-0.000 \\
(0.002)\end{array}$ & $\begin{array}{c}0.000 \\
(0.008)\end{array}$ & $\begin{array}{c}0.002 \\
(0.002)\end{array}$ & $\begin{array}{l}-0.003 \\
(0.003)\end{array}$ \\
\hline \multicolumn{6}{|c|}{$\begin{array}{l}\text { Notes: Each cell represents a separate regression, and all regressions include variables excluding assets appearing } \\
\text { in Tables 3-6. Dependent variable is the narrow migration measure. Standard errors clustered at the enumeration } \\
\text { area level. *- indicates significance at the } 10 \text { percent level; }{ }^{* *} \text { - indicates significance at the } 5 \text { percent level; ***- } \\
\text { indicates significance at the } 1 \text { percent level. } \\
\text { Sources: Bangladesh, BIHS } 2011 \text { and 2015; Indonesia, IFLS-4 and IFLS-5; Nigeria, NGHS } 2013 \text { and 2016; Pakistan, } \\
\text { PRHPS } 2012 \text { and 2014; Tanzania, TNPS 2008-9 and 2012-3. }\end{array}$} \\
\hline
\end{tabular}


Table 8. Association between Specific Village Level Variables and Narrow Measure of Migration, Panel Surveys

\begin{tabular}{lccccc}
\hline & Bangladesh & Indonesia & Nigeria & Pakistan & Tanzania \\
\hline Panel A: 15-24 year olds & & & & & \\
Village Land per Capita (ha) & -0.081 & -0.011 & -0.001 & $-0.030^{* *}$ & 0.004 \\
& $(0.117)$ & $(0.010)$ & $(0.014)$ & $(0.013)$ & $(0.023)$ \\
Share of Households with & $-0.068^{* *}$ & -0.020 & 0.010 & -0.038 & -0.032 \\
Off-Farm work & $(0.027)$ & $(0.028)$ & $(0.019)$ & $(0.026)$ & $(0.043)$ \\
Log, Population Density & $-0.016^{*}$ & $-0.024 * *$ & -0.003 & & $0.016^{*}$ \\
& $(0.009)$ & $(0.006)$ & $(0.004)$ & & $(0.010)$ \\
Enhanced Vegetation Index & -0.045 & -0.021 & -0.000 & & -0.025 \\
(3 year average) & $(0.072)$ & $(0.063)$ & $(0.001)$ & & $(0.081)$ \\
Panel B: 25-34 year olds & & & & & \\
Village Land per Capita (ha) & -0.105 & 0.006 & $-0.026 * * *$ & -0.026 & 0.043 \\
& $(0.108)$ & $(0.005)$ & $(0.009)$ & $(0.032)$ & $(0.040)$ \\
Share of Households with & -0.024 & $-0.033^{*}$ & 0.029 & -0.022 & 0.055 \\
Off-Farm work & $(0.028)$ & $(0.017)$ & $(0.021)$ & $(0.072)$ & $(0.071)$ \\
Log, Population Density & 0.010 & -0.001 & -0.004 & & 0.017 \\
& $(0.008)$ & $(0.004)$ & $(0.005)$ & & $(0.013)$ \\
Enhanced Vegetation Index & -0.035 & 0.029 & $0.002 * *$ & & -0.043 \\
(3 year average) & $(0.075)$ & $(0.033)$ & $(0.001)$ & & $(0.155)$ \\
\hline
\end{tabular}

Notes: Dependent variable is the narrow migration measure. Standard errors clustered at the enumeration area level, and all regressions include regional fixed effects and variables excluding assets appearing in Table 3-6. *indicates significance at the 10 percent level; ${ }^{* *}$ - indicates significance at the 5 percent level; ${ }^{* * *}$ - indicates significance at the 1 percent level.

Sources: Bangladesh, BIHS 2011 and 2015; Indonesia, IFLS-4 and IFLS-5; Nigeria, NGHS 2013 and 2016; Pakistan, PRHPS 2012 and 2014; Tanzania, TNPS 2008-9 and 2012-3; external sources are used for population density and is measured at the upazila level in Bangladesh. 
Appendix Table A1. Descriptive Statistics, Variables Used, by Country

\begin{tabular}{|c|c|c|c|c|c|}
\hline & $\begin{array}{c}(1) \\
\text { Bangladesh }\end{array}$ & $\begin{array}{c}\text { (2) } \\
\text { Indonesia }\end{array}$ & $\begin{array}{c}(3) \\
\text { Nigeria }\end{array}$ & $\begin{array}{c}(4) \\
\text { Tanzania }\end{array}$ & $\begin{array}{c}\text { (5) } \\
\text { Pakistan }\end{array}$ \\
\hline \multicolumn{6}{|l|}{ Individual (Youth) Characteristics } \\
\hline \multirow[t]{2}{*}{ Gender (1=male) } & 0.460 & 0.503 & 0.540 & 0.509 & 0.488 \\
\hline & $(0.498)$ & $(0.500)$ & $(0.498)$ & $(0.500)$ & $(0.500)$ \\
\hline \multirow[t]{2}{*}{ Age } & 18.967 & 19.361 & 19.021 & 19.148 & 19.239 \\
\hline & $(2.928)$ & $(2.873)$ & $(2.864)$ & $(2.791)$ & $(2.827)$ \\
\hline \multirow[t]{2}{*}{ Less than Primary School } & 0.618 & 0.060 & 0.232 & 0.351 & 0.099 \\
\hline & $(0.486)$ & $(0.237)$ & $(0.422)$ & $(0.477)$ & $(0.298)$ \\
\hline \multirow[t]{2}{*}{ Primary School Complete } & 0.216 & 0.537 & 0.474 & 0.481 & 0.363 \\
\hline & $(0.412)$ & (0.499) & $(0.499)$ & $(0.500)$ & $(0.481)$ \\
\hline \multirow[t]{2}{*}{ Secondary School Complete } & 0.093 & 0.256 & 0.125 & 0.060 & 0.160 \\
\hline & $(0.291)$ & $(0.437)$ & $(0.330)$ & $(0.237)$ & $(0.366)$ \\
\hline \multirow[t]{2}{*}{ More than Secondary School } & 0.000 & 0.141 & 0.008 & 0.000 & 0.009 \\
\hline & $(0.021)$ & $(0.348)$ & $(0.090)$ & $(0.020)$ & $(0.094)$ \\
\hline \multirow[t]{2}{*}{ Child of household head } & 0.762 & 0.638 & 0.846 & 0.695 & 0.794 \\
\hline & $(0.426)$ & $(0.481)$ & $(0.361)$ & $(0.460)$ & $(0.405)$ \\
\hline \multicolumn{6}{|l|}{ Household Demographics } \\
\hline \multirow[t]{2}{*}{ Household size } & 5.108 & 5.005 & 8.137 & 7.390 & 7.931 \\
\hline & $(1.863)$ & $(1.967)$ & $(3.328)$ & $(4.057)$ & $(3.550)$ \\
\hline \multirow[t]{2}{*}{ Share of Household, Female } & 0.521 & 0.505 & 0.494 & 0.526 & 0.490 \\
\hline & $(0.178)$ & $(0.194)$ & $(0.167)$ & $(0.192)$ & $(0.146)$ \\
\hline \multirow[t]{2}{*}{ Share of Household, Elderly } & 0.041 & 0.053 & 0.038 & 0.034 & 0.026 \\
\hline & $(0.092)$ & $(0.135)$ & $(0.093)$ & $(0.088)$ & $(0.068)$ \\
\hline \multirow[t]{2}{*}{ Share of Household, Youth } & 0.271 & 0.198 & 0.266 & 0.263 & 0.350 \\
\hline & $(0.193)$ & $(0.203)$ & $(0.174)$ & $(0.186)$ & $(0.183)$ \\
\hline \multirow[t]{2}{*}{ Share of Household, under 5} & 0.060 & 0.067 & 0.090 & 0.124 & 0.064 \\
\hline & $(0.105)$ & $(0.104)$ & $(0.112)$ & (0.119) & $(0.102)$ \\
\hline \multirow[t]{2}{*}{ Age of household head } & 46.685 & 46.704 & 52.793 & 49.285 & 48.401 \\
\hline & $(12.848)$ & $(19.215)$ & $(12.354)$ & $(12.983)$ & $(13.854)$ \\
\hline Gender of household head & 0.169 & 0.853 & 0.096 & 0.774 & 0.951 \\
\hline (1=male) & $(0.375)$ & $(0.354)$ & $(0.295)$ & $(0.418)$ & $(0.216)$ \\
\hline \multirow[t]{2}{*}{ Head has no education } & 0.513 & 0.107 & 0.009 & 0.297 & 0.008 \\
\hline & $(0.500)$ & $(0.310)$ & $(0.095)$ & $(0.457)$ & $(0.090)$ \\
\hline Head has primary school & 0.179 & 0.555 & 0.493 & 0.490 & 0.358 \\
\hline education or more & $(0.384)$ & $(0.497)$ & $(0.500)$ & $(0.500)$ & $(0.479)$ \\
\hline \multicolumn{6}{|l|}{ Household Asset Holdings } \\
\hline \multirow[t]{2}{*}{ Owns furniture? } & 0.985 & 0.982 & 0.973 & 0.958 & 0.600 \\
\hline & $(0.123)$ & $(0.134)$ & $(0.163)$ & $(0.200)$ & $(0.490)$ \\
\hline \multirow[t]{2}{*}{ Owns vehicle? } & 0.077 & 0.556 & 0.612 & 0.029 & 0.273 \\
\hline & $(0.266)$ & $(0.497)$ & $(0.487)$ & $(0.167)$ & $(0.445)$ \\
\hline \multirow[t]{2}{*}{ Owns consumer durables? } & 0.335 & 0.846 & 0.443 & 0.581 & 0.822 \\
\hline & $(0.472)$ & $(0.361)$ & $(0.497)$ & $(0.493)$ & $(0.383)$ \\
\hline \multirow[t]{2}{*}{ Own house? } & 0.949 & 0.881 & 0.960 & 0.963 & 0.879 \\
\hline & $(0.220)$ & $(0.324)$ & $(0.196)$ & $(0.190)$ & $(0.326)$ \\
\hline Observations & 4293 & 4061 & 4068 & 2448 & 2833 \\
\hline
\end{tabular}

Notes: Standard deviations in parentheses.

Sources: Bangladesh, BIHS 2011-2015; Indonesia, IFLS 4 and 5; Nigeria, NGHS 203 and 2016; Pakistan, PRHPS 2012 and 2014; Tanzania, TNPS 2008-9 and 2012-3; Mexico, Mexican Migration Project, 2008-2016; Nepal, NLSS-3, 2010. 


\section{ALL IFPRI DISCUSSION PAPERS}

All discussion papers are available here

They can be downloaded free of charge

INTERNATIONAL FOOD POLICY RESEARCH INSTITUTE www.ifpri.org

\section{IFPRI HEADQUARTERS}

1201 Eye Street, NW

Washington, DC 20005 USA

Tel.: +1-202-862-5600

Fax: $+1-202-862-5606$

Email: ifpri@cgiar.org 